
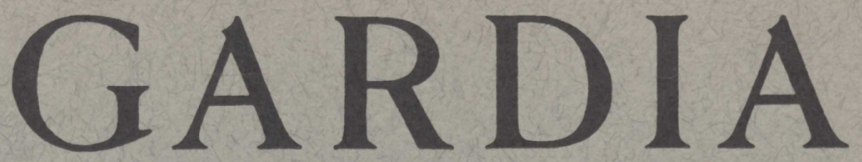

A Journal of Agricultural Science Published by the California Agricultural Experiment Station

\title{
THE INFLUENCE OF TEMPERATURE AND OXYGEN LEVEL ON THE RESPIRATION AND RIPENING OF WICKSON PLUMS
}

\author{
L. L. CLAYPOOL and F. W. ALLEN
}

UNIVERSITY OF CALIFORNIA • BERKELEY, CALIFORNIA 
This paper presents some recent studies on the influence of atmospheres, modified as to their oxygen level and temperature, on the storage life of Wickson plums. Nine temperatures $\left(32^{\circ}-95^{\circ} \mathrm{F}\right)$ were used at each of ten oxygen levels (1-100 per cent).

The results show that fruits reached respiration and ripening peaks fastest at $77^{\circ}$ in the temperature series, although initial $\mathrm{CO}_{2}$ production increased with temperature to the $95^{\circ}$ level. In the oxygen series, the rate of acceleration was roughly proportional to the oxygen tension. Respiration and ripening were increasingly delayed in the lower oxygen levels and at reduced temperatures.

At increasing temperatures, fruits in the lowest oxygen levels began to produce as much or more $\mathrm{CO}_{2}$ as fruits in next highest oxygen levels; at $77^{\circ}$ the 10 per cent oxygen lot was surpassed by the three lower oxygen lots in reverse order. This is attributed to anaerobic respiration not balanced by the aerobic phases.

Ripening failures and loss of vitality of all oxygen lots at $86^{\circ}$ and $95^{\circ}$ are thought to have resulted from disturbances of the enzyme systems under high temperature. 


\section{$\begin{array}{lllllllllllllll}H & I & L & G & A & R & D & I & A\end{array}$}

A Journal of Agricultural Science Published by

the California Agricultural Experiment Station

VoL. 21

NOVEMBER, 1951

No. 6

\section{THE INFLUENCE OF TEMPERATURE AND OXYGEN LEVEL ON THE RESPIRATION AND RIPENING OF WICKSON PLUMS ${ }^{1}$}

\section{L. CLAYPOOL ${ }^{2}$ and F.W. ALLEN ${ }^{3}$}

THERE HAS FOR MANY years been interest in the influence of atmospheres other than air on the storage life of various harvested fruits. A great deal of attention has been given to atmospheres containing rather substantial amounts of carbon dioxide (5-60 per cent). Much of this work was stimulated by early studies in England of Kidd, West, and Kidd (1927), who found that the storage life of certain apple varieties under refrigeration might be greatly extended by storing them in atmospheres of the proper composition. Some commercial application has been made in England, the Union of South Africa, and more recently in New York of so-called "gas" storage, where $\mathrm{CO}_{2}$ is added or allowed to accumulate in storage rooms and oxygen depleted accordingly.

Studies are very limited relative to the influence on storage life of fruit of atmospheres modified as to their oxygen level, although the chemistry of respiration would lead one to expect such changes to have a profound effect on the respiratory processes. Goddard and Meeuse (1950) and Biale (1950) have in recent reviews summarized much of the later work relating to the influence of oxygen tension upon respiration and physiology. While experiments with tissue slices have shown that an extremely low oxygen tension in the atmosphere surrounding living cells is sufficient to supply the respiratory requirements, these studies cannot be applied directly to whole fruits. The oxygen tension surrounding fruit tissues is tremendously influenced by the permeability of the epidermal layer, the rate of diffusion of oxygen through the fruit, the size of fruit, and temperature. Unfortunately, there are no suitable methods available for measuring oxygen under these conditions.

We reported (Claypool and Allen, 1948) the results of respiration studies made in 1946 of fruits in atmospheres of different oxygen level at $65^{\circ}$ and $40^{\circ} \mathrm{F}$. Cherries and apricots failed to show an increase in respiration rate at

${ }^{1}$ Received for publication December 28, 1950.

2 Associate Professor of Pomology and Associate Pomologist in the Experiment Station, Davis.

${ }^{8}$ Professor of Pomology and Pomologist in the Experiment Station, Davis.

"See "Literature Cited" for citations, referred to in the text by author and date. 
either temperature as the oxygen level was increased above that in air to approximately 100 per cent (99+ by analysis). At levels of $2 \frac{1}{2}, 5,10$ and 15 per cent oxygen, respiration rates diminished as the oxygen level was lowered. In 1947 further experiments were made in which the lowest oxygen level was dropped from $21 / 2$ to 1 per cent, and a relatively constant temperature averaging about $73^{\circ} \mathrm{F}$ was added to the temperature series. Respiration rates of apricots, cherries, grapes, peaches and pears were not accelerated by oxygen concentrations above that in air, but the Wickson plum held only at $73^{\circ} \mathrm{F}$ showed greatly accelerated respiration and ripening at the high oxygen levels. The Wickson plum also varied from other fruits at low oxygen levels at $73^{\circ} \mathrm{F}$. It produced as much or more $\mathrm{CO}_{2}$ when held in 1 and $2 \frac{1}{2}$ per cent oxygen than in 5 per cent oxygen, whereas fruits of other species respired $\mathrm{CO}_{2}$ in diminishing amounts as the oxygen concentration was reduced from 21 to 1 per cent. It seems likely that the difference in response of the Wickson plum from that of the peach or apricot is related to the relatively impervious epidermal layer of the plum, which greatly modifies its internal oxygen condition in comparison with that of the other stone fruits.

The behavior of the Wickson plum stimulated our further interest in the physiology of this fruit, and resulted in a greatly enlarged study of respiration and ripening as related to temperature and oxygen level. Most of the study was completed in 1948, but some rechecks were made in 1949 and in addition an oxygen series at $95^{\circ} \mathrm{F}$ was added.

\section{TERMINOLOGY}

Before developing further the studies reported here we will define the terminology of respiration used in this paper. The term respiration here refers to the degradation and oxidation of substrate, which is evidenced by the production of carbon dioxide. The term anaerobic respiration refers to that part of respiration involving the degradation of substrate and the utilization of oxygen within the organic molecule or molecules rather than molecular oxygen. Many investigators prefer to use the term "fermentation" for this process, but there is not complete agreement as to its meaning. The term aerobic respiration refers to that part of respiration involving oxidation to intermediate or end products, where molecular oxygen serves as the electron acceptor. Those who prefer "fermentation" to anaerobic respiration usually would use the term "respiration" in place of the term aerobic respiration as used here.

\section{METHODS}

Prior to this experiment, our studies with modified atmospheres made at temperatures above those normally used for prolonged storage were primarily in relation to transit periods of 10 days duration. We have shown in simulated transit tests of 10 days, a time comparable to that required for transcontinental shipment of refrigerator cars by rail freight, that certain fruits would carry satisfactorily without refrigeration providing the proper atmosphere was maintained around the product (Claypool and Allen, 1947). In the studies reported here, consideration was given at the one extreme to a 10-day test period as used in preliminary tests in 1947, so that the results would have application to transit conditions, and at the other extreme to prolonging the 
tests to the end of the storage life of each lot. This latter consideration was modified because of being impractical where such a large number of treatments was involved, and where it would be necessary to make periodic removal of some fruits of each lot to a ripening temperature in order to ascertain the effect of the treatments more correctly. An arbitrary treatment time of 21 days was finally selected for tests in both 1948 and 1949. We believe this to have been sufficiently long to develop considerable information concerning the influence of oxygen on the respiration and ripening of the Wickson plum.

The plums in the 1948 experiment were harvested on July 14 from an orchard at Winters at the shipping maturity of light green with straw color near the tip. After careful grading and selection for uniform color, they were weighed and placed in respiration chambers the same day in 10 levels of oxygen at each of eight temperatures. Each lot contained 22 fruits weighing about 1500 grams. The oxygen levels approximated very closely the following percentages : $1,21 / 2,5,10,15,21,30,50,75$ and 100 . These were secured by a continuous mixing of air with nitrogen or oxygen measured by means of flowmeters to give the oxygen level and rate of flow desired. Except in a few cases where the respiration rate was very high, the rate of flow through the respiration chambers was sufficient to keep the $\mathrm{CO}_{2}$ content in the exhaust air from the chamber continuously below 0.5 per cent. The constant-temperature rooms in which tests were conducted were held at about $32,37,42,50,59,68$, 77 and $86^{\circ} \mathrm{F}$. These temperatures were chosen in relation to the centigrade scale representing a $5^{\circ} \mathrm{C}$ sequence except for $37^{\circ}$ and $42^{\circ} \mathrm{F}$. Respiration measurements were made daily during the 21 days of the experiment using the colorimetric method previously described. (Claypool and Keefer, 1942). New indicator was used for each reading, and all respiration equilibrations were made with the colorimeter tubes held in water baths adjusted to the temperature of the room in which the colorimeter reading was to be made.

Observations of fruit ripening were made at intervals, first of four days and later of two days, and were recorded numerically in accordance with the following schedule:
1. green
2. light green
3. yellowish green
4. greenish yellow
5. yellow

\author{
6. orange yellow \\ 7. reddish yellow (eating ripe) \\ 8. yellowish red \\ 9. light red \\ 10. red
}

At the beginning of the experiment the fruits were of a light green color (numerical rating 2). Following 21 days in differential treatments all fruits not already ripe were removed to air at $68^{\circ} \mathrm{F}$ and held until the ripening processes were completed. Taste tests were made on ripe fruit to determine any development of abnormal flavors.

In 1949 the methods employed were similar to those used in 1948, but the tests were restricted to those temperatures and oxygen levels where additional information appeared desirable on the basis of previous results. This included the addition of a complete oxygen series at $95^{\circ} \mathrm{F}$. 


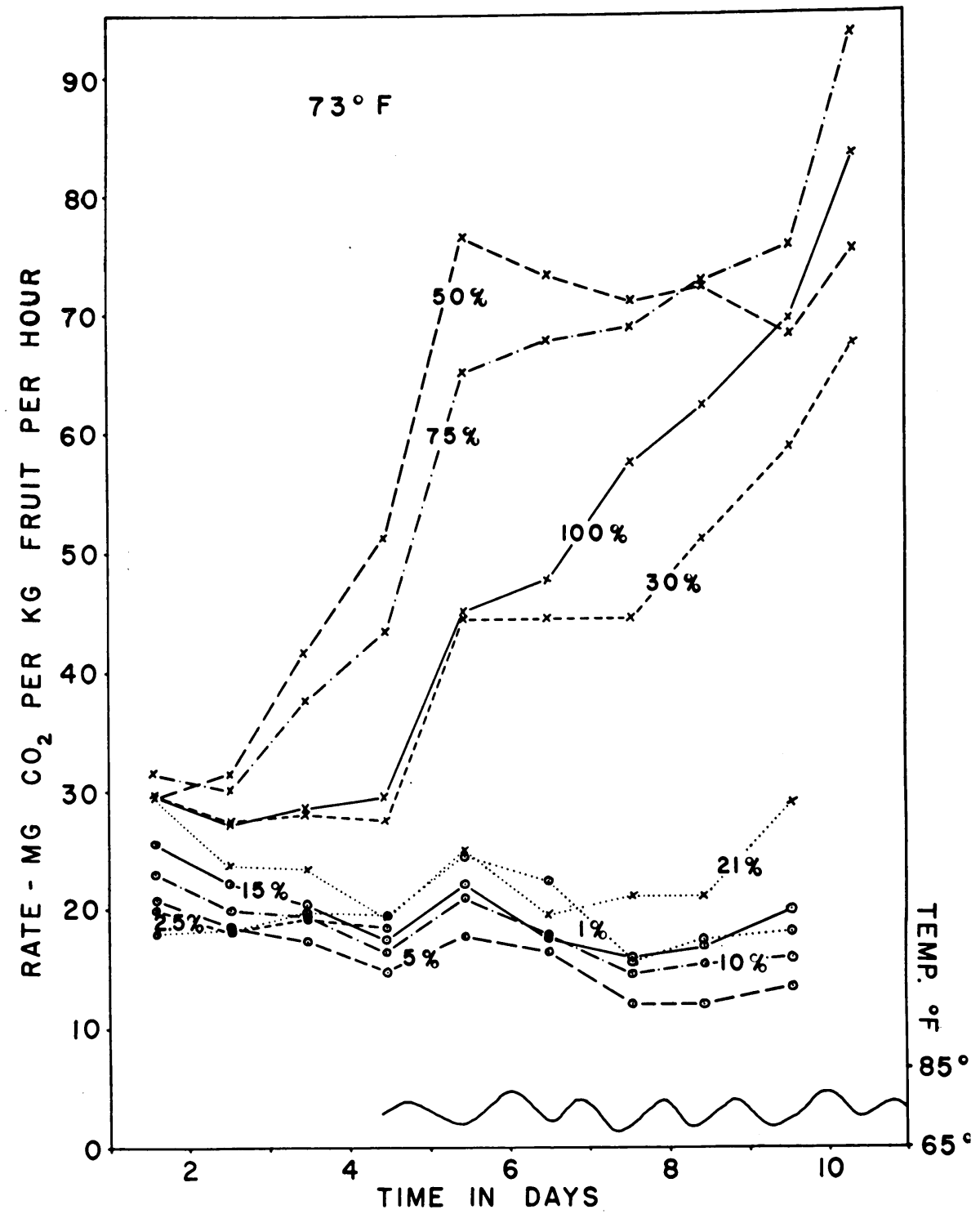

Fig. 1. Respiration of Wickson plums held in different oxygen atmospheres at a fluctuating temperature averaging $73^{\circ} \mathrm{F}, 1947$.

\section{RESULTS: 1947 DATA}

In 1947 the period of differential treatment was 10 days at a temperature fluctuating between 70 and $75^{\circ} \mathrm{F}$ and averaging about $73^{\circ} \mathrm{F}$. Respiration data are shown in figure 1 for the differential treatment period.

A rapid acceleration in respiration rate occurred as oxygen was increased above the level in air. The greatest acceleration occurred in 50 and 75 per 
cent oxygen. The respiration rate of fruit in 100 per cent oxygen was considerably less than in 50 or 75 per cent oxygen, and for the first half of the respiration period was only slightly greater than in 30 per cent oxygen. In oxygen levels of air and below, respiration did not increase but actually decreased slightly from the beginning to the end of differential treatments. The respiration rates of the fruit in the $5,10,15$, and 21 per cent oxygen lots were considerably below those in the higher oxygen concentrations and in general increased only slightly with increased oxygen level. The 1 per cent oxygen lot, instead of being lower in $\mathrm{CO}_{2}$ production than others as expected, was about equal to the 15 per cent oxygen lot. Unfortunately the $21 / 2$ per cent lot was lost early due to Rhizopus infection but its behavior prior to this time was somewhat similar to the 1 per cent lot.

Changes in color and ripening were associated with respiration rates. The 50 to 75 per cent lots were light red and ripe on the sixth day of the test, the 100 per cent lot on the eighth day and the 30 per cent lot on the tenth day. All others were greatly delayed in ripening, requiring 15 or more days after removal to air at $65^{\circ} \mathrm{F}$. The flavors of all fruits were normal except those held in 1 per cent oxygen which were slightly off flavor when ripe.

\section{RESULTS: 1948 AND 1949 DATA}

\section{Respiration at Different Temperatures in Relation to Oxygen Level}

The respiration curves for 1948 at the eight temperatures used are shown in figures 2 to 9 . Continuous room-temperature records are shown at the lower part of each figure with a temperature scale on the right hand margin.

At $32^{\circ} \mathrm{F}$. The respiration rates at $32^{\circ} \mathrm{F}$ (figure 2 ) are in general directly related to the oxygen level, increasing as the oxygen level is elevated. The actual differences in respiration rates are small due to the temperature effect in retarding respiration, but with the exception of minor fluctuations of the curves, relative differences seem to be real. The trend of all lots is for the respiration rate to increase slightly with time.

At $37^{\circ} \mathrm{F}$. At $37^{\circ} \mathrm{F}$ (figure 3) respiration of the fruit is about 50 per cent greater than that of the comparable lots at $32^{\circ}$ and shows a wider spread between lots in the different atmospheres.

As at $32^{\circ} \mathrm{F}$, the respiration rates are closely related to the oxygen level, increasing as the amount of oxygen is increased although not in the same proportion. Differences are quite marked and consistent at 21 per cent oxygen and below, but above 21 per cent oxygen differences are neither great nor consistent. All lots exhibit an increase in respiration rate with time, although a downward trend may occur for the first four or five days before the rise begins. The increase in respiration rate is somewhat greater in fruits in 15 per cent oxygen and above than those at lower levels.

At $42^{\circ} \mathrm{F}$. When the temperature was raised from 37 to $42^{\circ} \mathrm{F}$ (figure 4 ) the average respiration rates increased about 60 per cent in value. At oxygen levels of air and below the respiration rates were well spread and appear directly related to the oxygen concentration in the atmosphere. However, at 21 per cent oxygen and above there is no consistent relationship between the oxygen level and the respiration rate. These inconsistencies appear to be due 


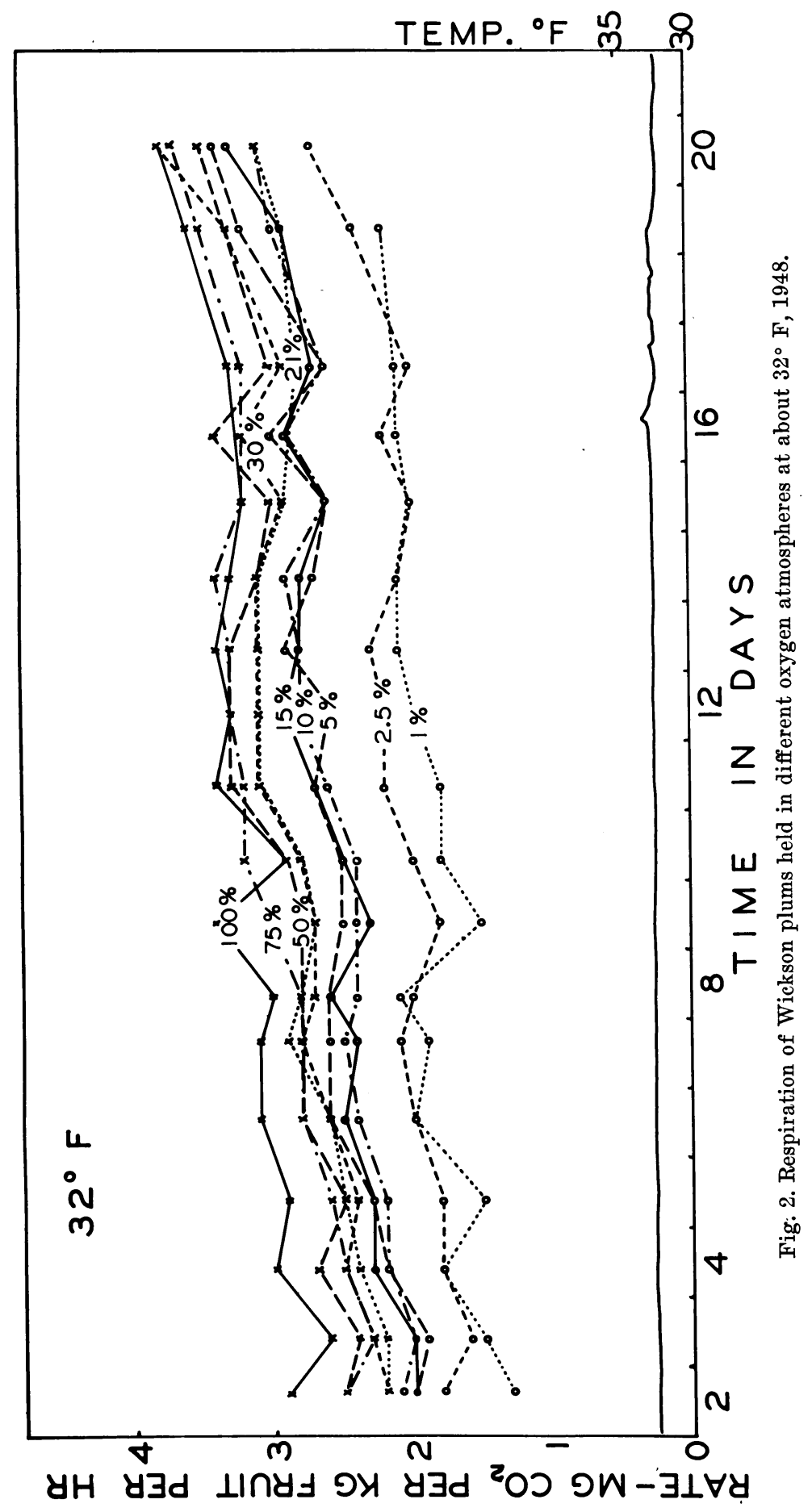




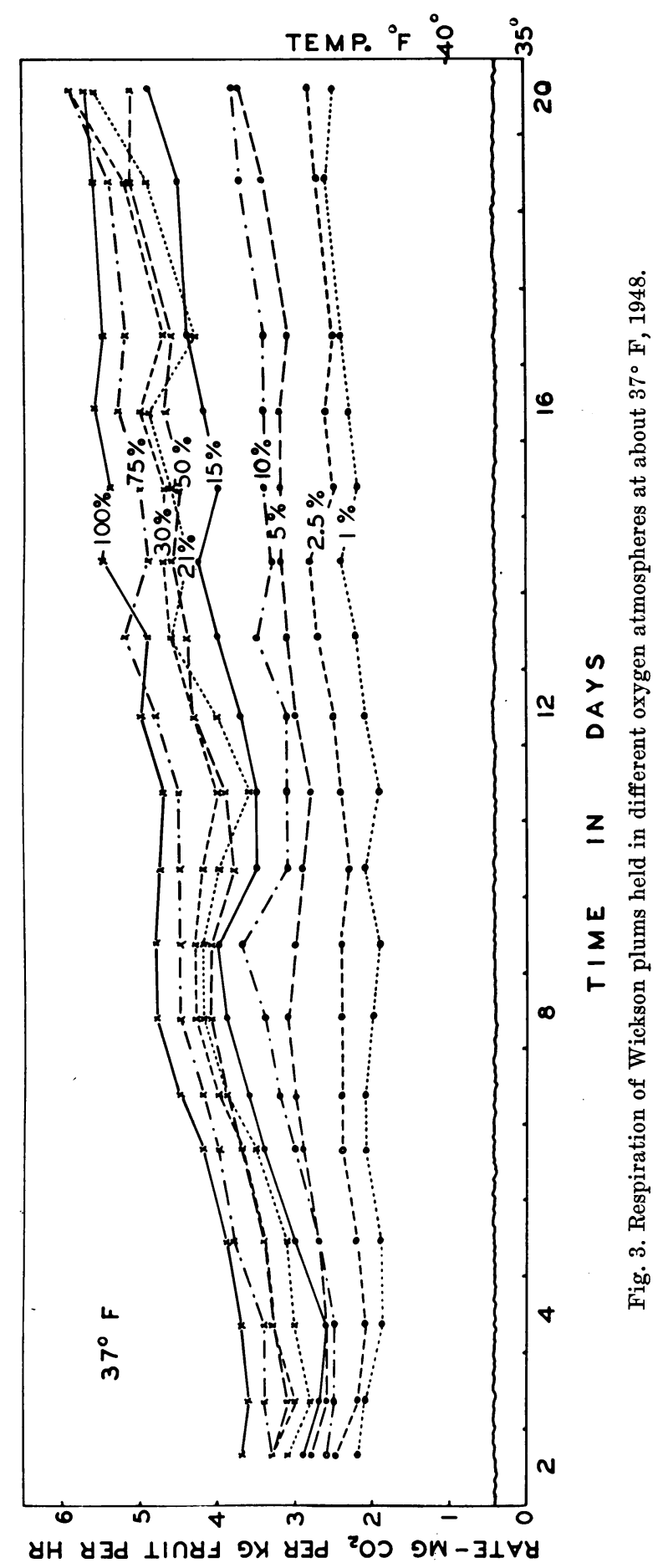




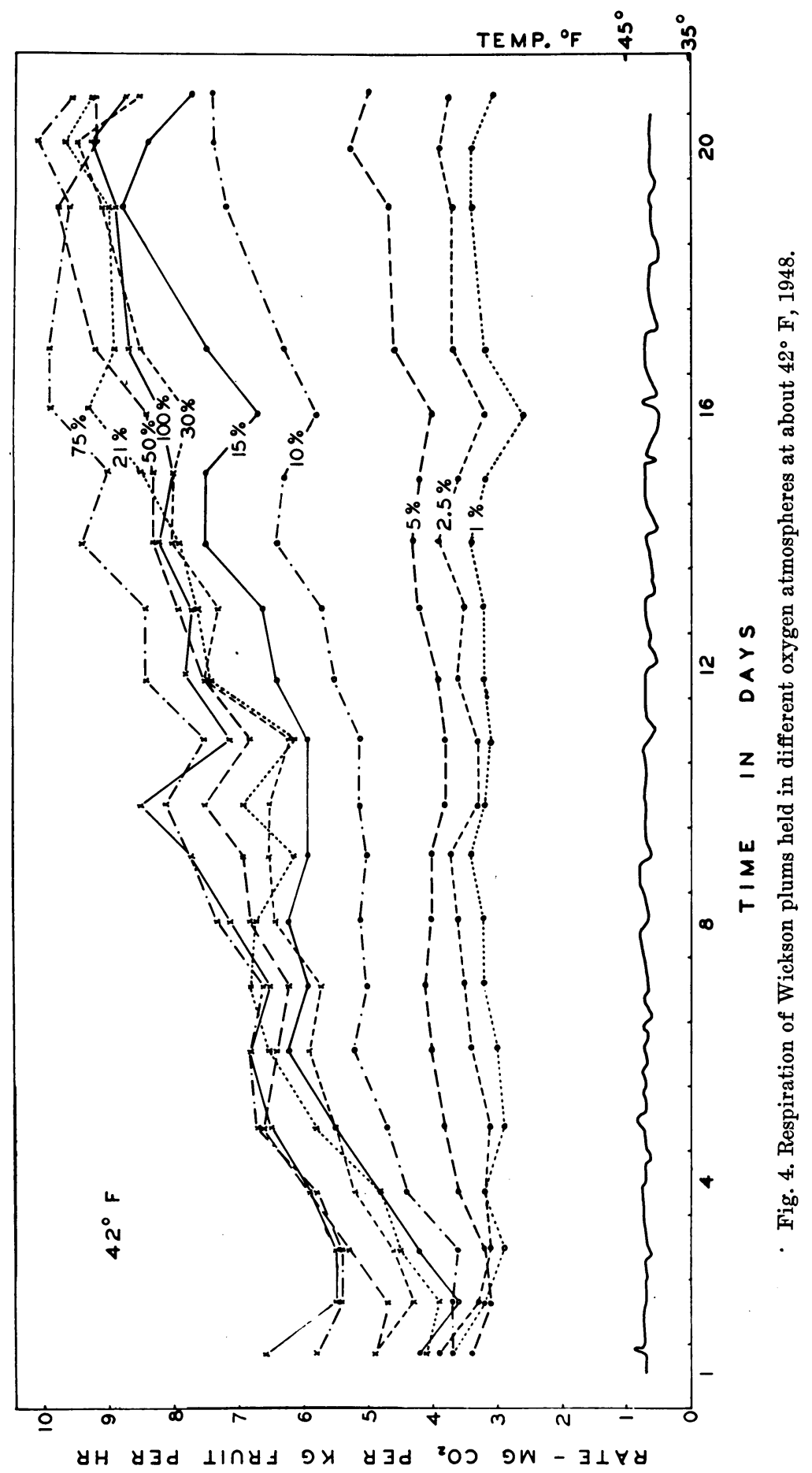


to the positions of the curves of the 21 and 100 per cent oxygen lots. After an initial drop, respiration rates increase with time, the magnitude of the increase being greater as the oxygen level is raised.

At $50^{\circ} \mathrm{F}$. Respiration rates at $50^{\circ} \mathrm{F}$ (figure 5 , drawn on a different ordinate axis than figures 2, 3 and 4) are approximately in the order of the per cent oxygen in the atmosphere except for the 15 per cent level which appears out of line. The respiration rates of the 1 and $21 / 2$ per cent oxygen lots as measured by $\mathrm{CO}_{2}$ production are almost identical, in contrast to consistent differences at the three lower temperatures. At oxygen levels of 10 per cent and below the respiration rates remained approximately constant throughout the period of differential treatment, but at higher oxygen concentrations the respiration rates just about doubled during the test period. It is doubtful whether the climacteric peak of respiration was reached in any lot at $50^{\circ} \mathrm{F}$ during the period of test, but it was approached in the high oxygen lots as indicated by a leveling of the respiration curves near the end of the treatment period. Because of the unexpected position of the 15 per cent oxygen curve this lot was rechecked in duplicate against air in 1949. The duplicates had nearly identical respiration curves which placed them between the 10 and 21 per cent oxygen curves of 1948. It is believed, therefore, that some unknown condition was responsible for the abnormal position of the 15 per cent curve in 1948 and that the normal curve should be in a position between that of air and 10 per cent oxygen, as shown for the 1949 duplicate lots in figure 5 .

At $59^{\circ} \mathrm{F}$. At $59^{\circ} \mathrm{F}$ (figure 6 ) the respiration rates of fruits of all lots held in atmospheres containing more oxygen than that in the air were greatly accelerated. Except for the reversal of position between the 50 and 75 per cent oxygen lots the respiration rates are in the order of oxygen concentration. The 100, 75 and 50 per cent oxygen lots all reached the climacteric peak of respiration during the 21 day period of treatment with the 100 per cent lot reaching the peak about two days ahead of the others. At oxygen levels of air and below, respiration intensity remained approximately constant during the differential treatment period and is closely associated with oxygen level, except for the 1 and $2 \frac{1}{2}$ per cent lots which respired at about the same rate as the 5 per cent lot. This point is extremely interesting and suggests the possibility that $\mathrm{CO}_{2}$ production alone at these low levels of oxygen does not reflect true energy release relationships, but that a certain degree of intramolecular respiration occurred which was not subsequently balanced by the aerobic phases. At $50^{\circ} \mathrm{F}$ the position of the 1 per cent oxygen curve in relation to the $21 / 2$ per cent $\mathrm{O}_{2}$ curve would also suggest such an explanation.

At $68^{\circ} \mathrm{F}$. The relationship between respiration rate and oxygen level at $68^{\circ} \mathrm{F}$ (figure 7 ) is very erratic when compared to the order that existed at lower temperatures. Three things stand out at this temperature: (1) the relative positions of the 1 and $2 \frac{1}{2}$ per cent $\mathrm{O}_{2}$ curves, (2) the acceleration of respiration resulting from increasing the partial pressure of oxygen, and (3) the low position of the 100 per cent $\mathrm{O}_{2}$ curve.

The 1 and $2 \frac{1}{2}$ per cent $\mathrm{O}_{2}$ curves started lower than any others but within eight days had surpassed even the 15 per cent $\mathrm{O}_{2}$ curve. This behavior can be construed as further evidence supporting the belief that energy release was primarily by molecular degradation without corresponding oxidation due to 


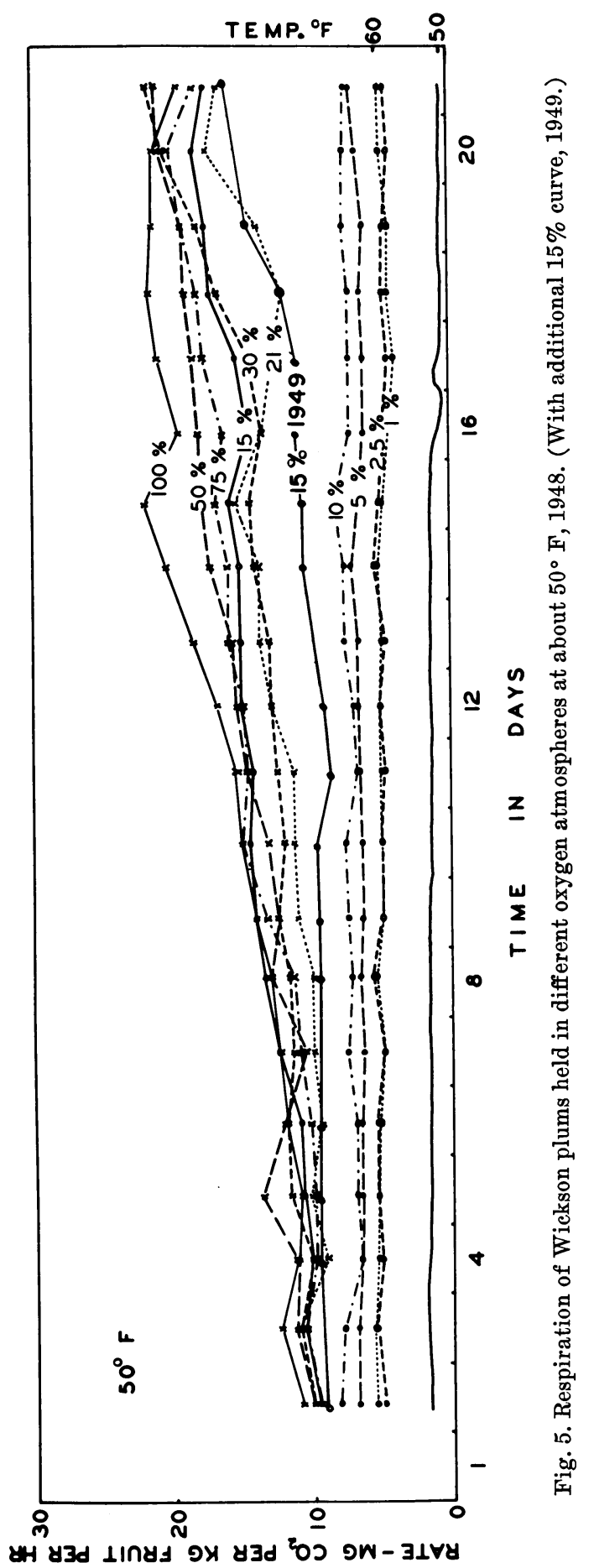




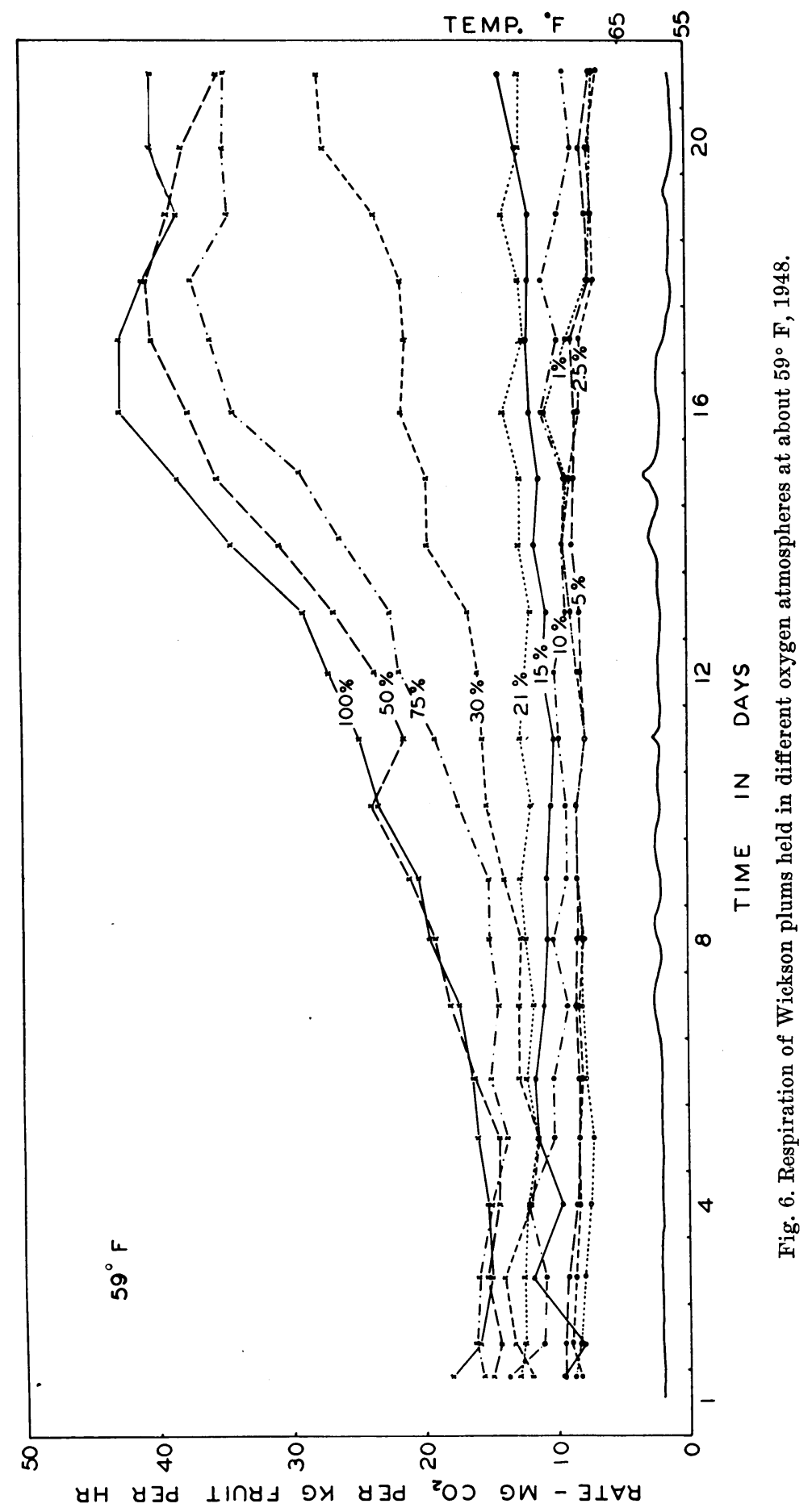




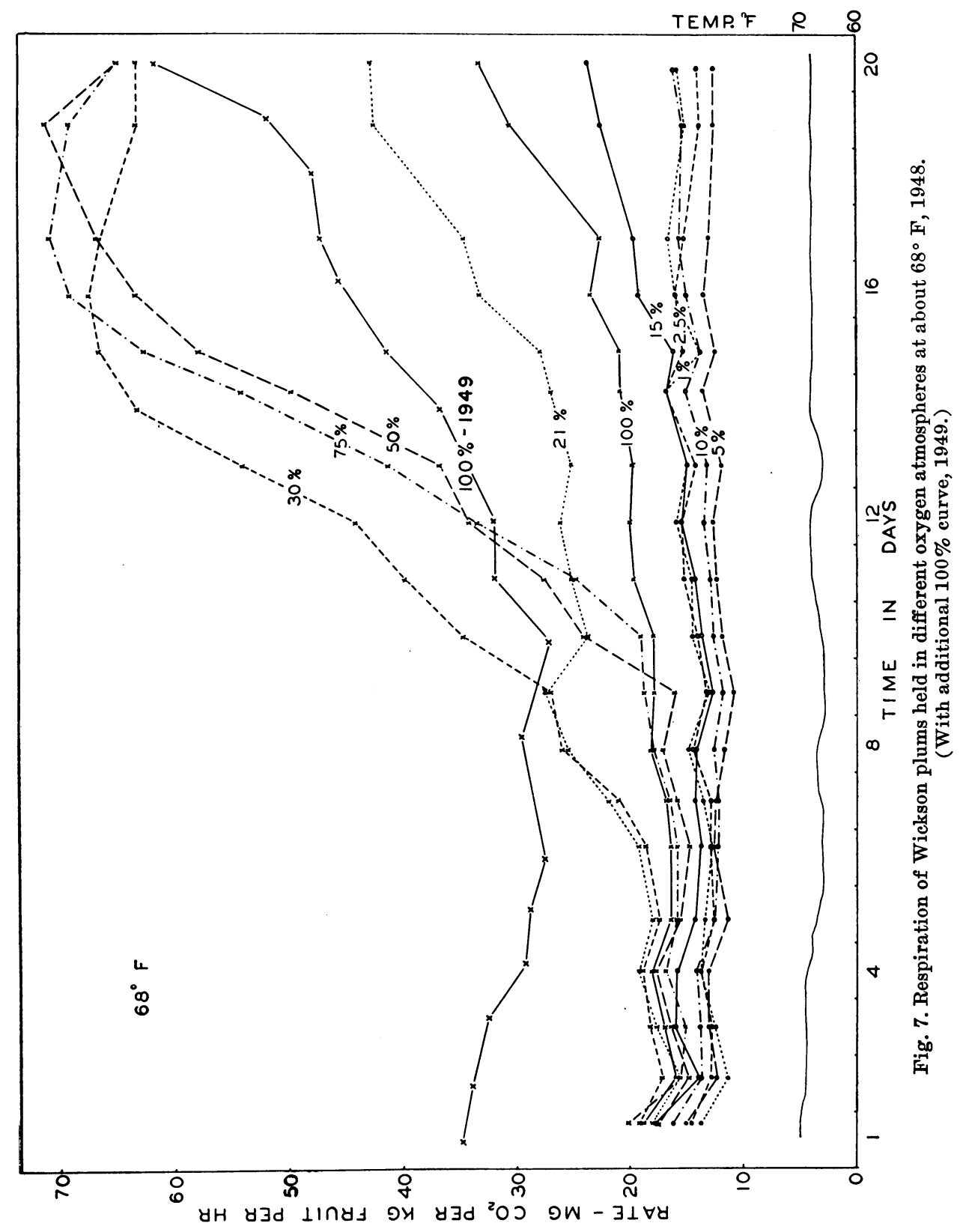


the near absence of oxygen in much of the fruit tissue. If this is true, it seems likely that even with greater $\mathrm{CO}_{2}$ production by the 1 and $2 \frac{1}{2}$ per cent $\mathrm{O}_{2}$ lots, energy changes were probably less than in the 5 and 10 per cent $\mathrm{O}_{2}$ lots, which apparently respired at lower rates due to the limited energy release from molecular degradation and decarboxylation.

The accelerating effect of high oxygen concentrations is considerably greater than at any lower temperatures. After an initial relatively level period lasting for 10 days, all of the curves of the high oxygen lots except the 100 per cent lot rose rapidly to the climacteric peak which was reached five to eight days later. We are unable to explain satisfactorily the behavior of the 100 per cent oxygen curve as a rapid rise was expected similar to other high oxygen lots. It is apparent that the trigger action responsible for starting the metabolic surge did not develop. In 1949 the 100 per cent oxygen curve was rechecked in duplicate and compared with curves of 50,30 and 21 per cent oxygen lots. Neither the air nor the 30 per cent lots began the climacteric rise during the 20 days in differential treatments. The 50 per cent lot began the rise after 14 days and the two 100 per cent lots after 10 and 18 days respectively. A curve representing the average of the two 1949100 per cent oxygen lots, also drawn in figure 7, shows fruits in this high oxygen level to behave more nearly as expected and indicates that the 1948 curve with respect to 100 per cent oxygen is not normal.

It is of interest in connection with the two 100 per cent oxygen lots to point out that one fruit more advanced physiologically than others of the same lot may influence the respiration rates of other fruits in the lot even where the calculated air change is once in 15 minutes. The respiration rate and ripening of fruits in one lot was somewhat more accelerated than the other. Upon examination one fruit was found somewhat advanced in color development and with decay just starting at an injury. This fruit was removed with the immediate result that the respiration rate of the entire lot dropped much more than could be accounted for by assuming a very high rate for the injured fruit. Furthermore the trigger action which had accelerated ripening changes apparently had not progressed to the point of being self-perpetuating, as further ripening lagged after the one riper fruit was removed. These observations indicate the importance of uniformity of fruits in experimental lots.

At $77^{\circ} \mathrm{F}$. The most rapid acceleration of respiration and the highest intensities were reached at $77^{\circ} \mathrm{F}$ (figure 8 ). This was most pronounced at the 75 per cent oxygen level where the climacteric peak was reached on the fourth day, followed closely by the 50 per cent oxygen lot where the peak was reached two days later. Although the 100 per cent oxygen lot was also greatly accelerated, the acceleration was less than that in the 75 and 50 per cent oxygen lots. These results are similar to those secured in 1947 at a temperature averaging $73^{\circ} \mathrm{F}$. In 1949 the 100 per cent oxygen lot was intermediate between the $\mathbf{7 5}$ and 50 per cent lots. Although the 75 per cent oxygen curve has been the highest consistently, it is not certain that the differences between it and the 100 per cent lot are real.

In contrast to the 1947 results, the air lot in 1948 also respired at an accelerated rate and attained the climacteric peak after seven to eight days, whereas in 1947 there was little change during the 10-day period of test. This differ- 
ence may be related to effects on the fruit of climatic differences of the two growing seasons, 1948 being much delayed in comparison to 1947. However, it should be mentioned that at the end of 11 days when the air lot was removed from the test, two fruits were found to be infested with the larvae of the peach

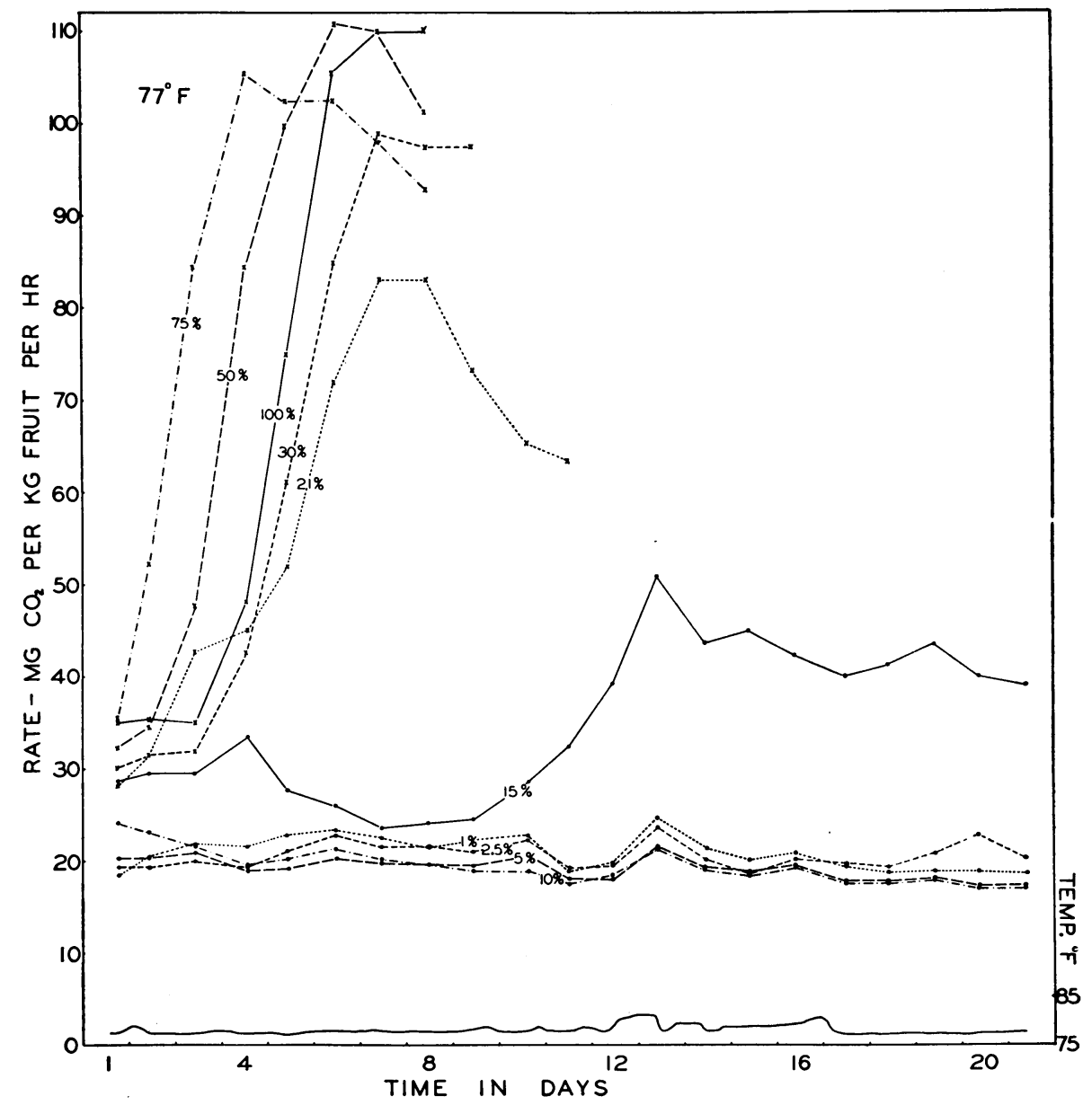

Fig. 8. Respiration of Wickson plums held in different oxygen atmospheres at about $77^{\circ} \mathrm{F}, 1948$.

twig. borer. These were the only wormy fruits found in the 80 lots under test. It is possible that the wormy fruits could have caused an acceleration of respiration of other fruits in the lot even though the air in the respiration chamber was changed every 15 minutes. In 1949 neither the air nor the 15 per cent oxygen lots approached the climacteric peak during the 20-day differential treatment period.

The respiration rates of fruits held in 10 per cent oxygen and below remained approximately constant during the 21 -day test period. Here, as at $68^{\circ}$ 
$\mathrm{F}$, the 1 and $21 / 2$ per cent oxygen lots were lowest in respiration rates at the beginning but within a few days they surpassed both the 5 and 10 per cent lots, and maintained this higher position throughout the remaining period of the experiment. The 5 per cent lot also slightly exceeded the 10 per cent lot

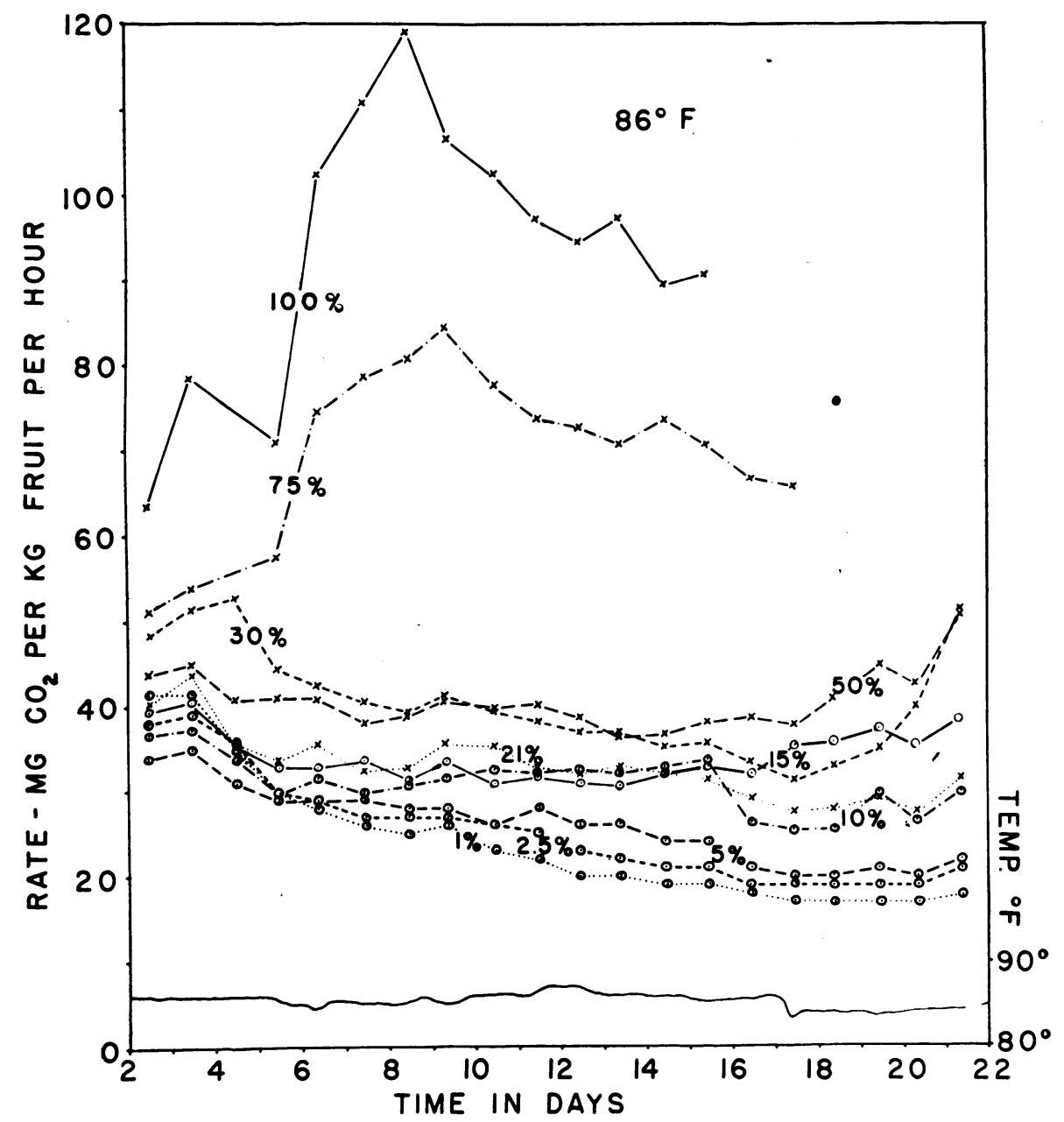

Fig. 9. Respiration of Wickson plums held in different oxygen atmospheres at about $86 \mathrm{~F}^{\circ}, 1948$.

during the last 12 days of the experiment, indicating that at $77^{\circ} \mathrm{F}$ the threshold level of oxygen below which anaerobic $\mathrm{CO}_{2}$ production was accelerated was well above 5 per cent in the external atmosphere.

At $86^{\circ} \mathrm{F}$. At $86^{\circ} \mathrm{F}$ (figure 9 ) only the 100 per cent and 75 per cent oxygen lots were accelerated in respiration. The 100 per cent oxygen lot had the highest respiration rate and reached the climacteric peak first. The 75 per cent oxygen lot apparently reached a respiration peak on the ninth day from which 
it receded slowly, perhaps because of a prolonged period during which individual fruits reached the peak of respiration on different days. All lots of fruit in 50 per cent oxygen or less diminished in respiration rate with time during most of the 21-day test period, and none of them reached the climacteric peak of respiration during this time, although it appears that the 30 and 50 per cent oxygen lots had begun to rise toward the climacteric peak at the end of the period of differential treatment. This is in marked contrast to the behavior at $77^{\circ} \mathrm{F}$. For the most part respiration rates seem to be closely related to the oxygen level. However, it should be noted that the 1 and $21 / 2$ per cent oxygen lots were well above the 5 and 10 per cent lots early in the period and remained so through the fifth day when they began to drop off rather rapidly. This behavior might well indicate that the early acceleration of anaerobic $\mathrm{CO}_{2}$ production disappeared because of the production of degradation products lethal to much of the protoplasm in interior tissues. This suggestion is supported by ripening and flavor data given later.

At $95^{\circ} \mathrm{F}$. The data at $95^{\circ} \mathrm{F}$ (figure 10) were secured in 1949 and although they are not exactly comparable with the 1948 data because of being from a different fruit crop, there is no reason to believe that they are other than typical.

The initial rate of $\mathrm{CO}_{2}$ production at all oxygen levels is somewhat higher than at any lower temperature. The apparent respiration rate as indicated by $\mathrm{CO}_{2}$ production dropped rapidly for the first two days, the greatest drops being at the lower oxygen levels. Following this initial period the curves tended to drop more slowly or level off. With minor variations the apparent respiration rates were in increasing order as the per cent oxygen was increased. None of the lots reached a normal climacteric peak during the period of differential treatment, although the 100 per cent oxygen lot gave indications of approaching such a peak in respiration. This is in strong contrast to results at $77^{\circ} \mathrm{F}$ and to a lesser extent at $86^{\circ} \mathrm{F}$. The orderly positions of the low oxygen curves might be considered to indicate that the threshold level of oxygen had not been reached at $95^{\circ} \mathrm{F}$. We believe on the contrary that the effect was so marked as to result in death of much protoplasm, so that $\mathrm{CO}_{2}$ production did not indicate the true condition of respiration. This will be discussed in more detail in the section on fruit ripening (p. 148).

\section{Respiration at Different Oxygen Levels in Relation to Temperature}

In order to relate respiration rate to temperature, figures 11,12 and 13 are presented to show the respiration rates as measured by $\mathrm{CO}_{2}$ production of all of the 5, 21 and 75 per cent oxygen lots respectively, at each of the nine temperatures. The 5 per cent oxygen series is used in preference to the 1 or $21 / 2$ per cent because of abnormalities related to anaerobic $\mathrm{CO}_{2}$ production that occurred in these latter two.

5 per cent Oxygen. Figure 11 shows the influence of temperature on fruits held in 5 per cent oxygen. It will be noted that without exception the respiration rate increased with temperature. The respiration rates increased slightly with time at the three lower temperatures, remained approximately level at $50^{\circ}, 59^{\circ}$, and $68^{\circ} \mathrm{F}$, and at the temperatures of $77^{\circ}, 86^{\circ}$ and $95^{\circ} \mathrm{F}$ actually diminished with time. 


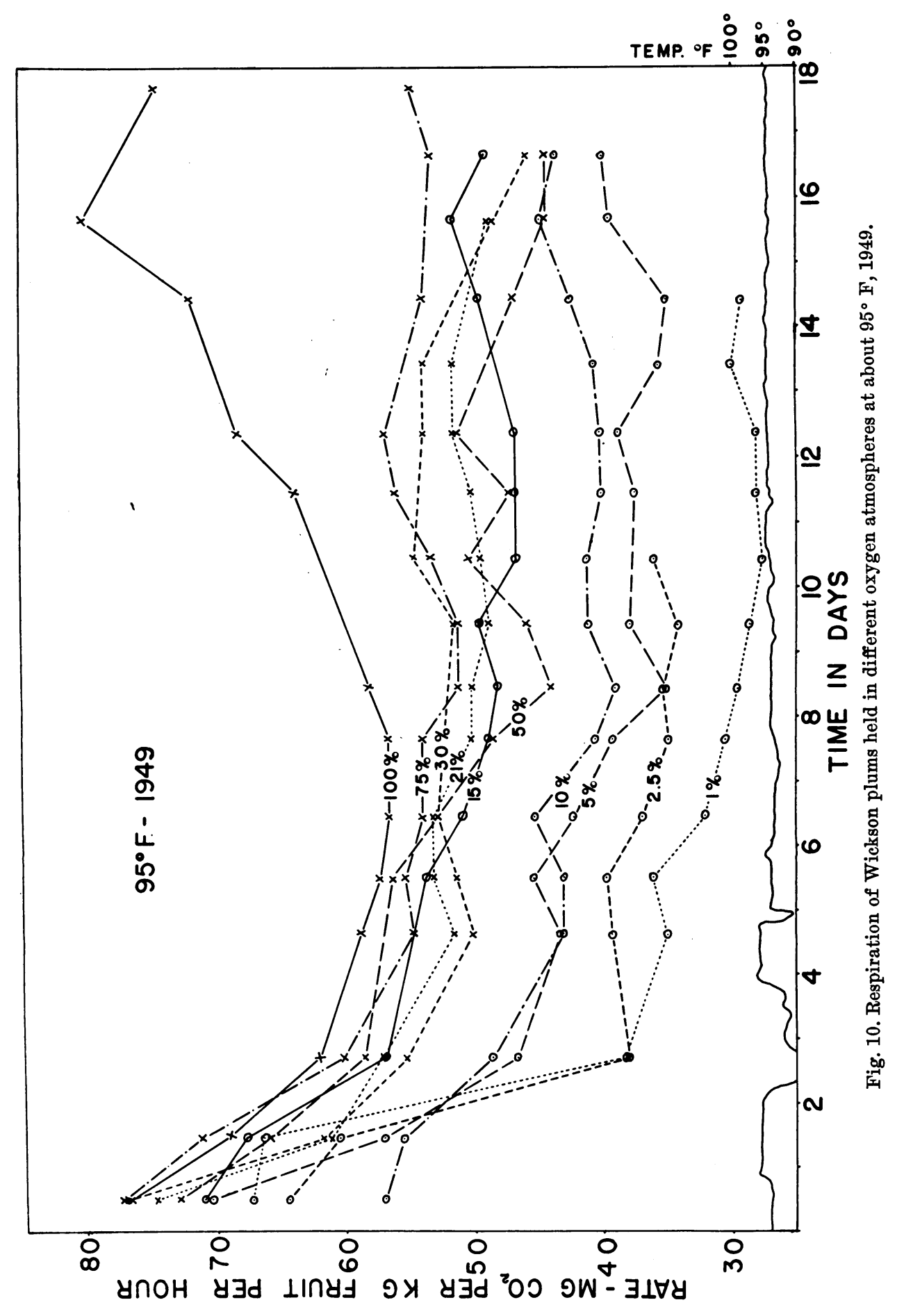




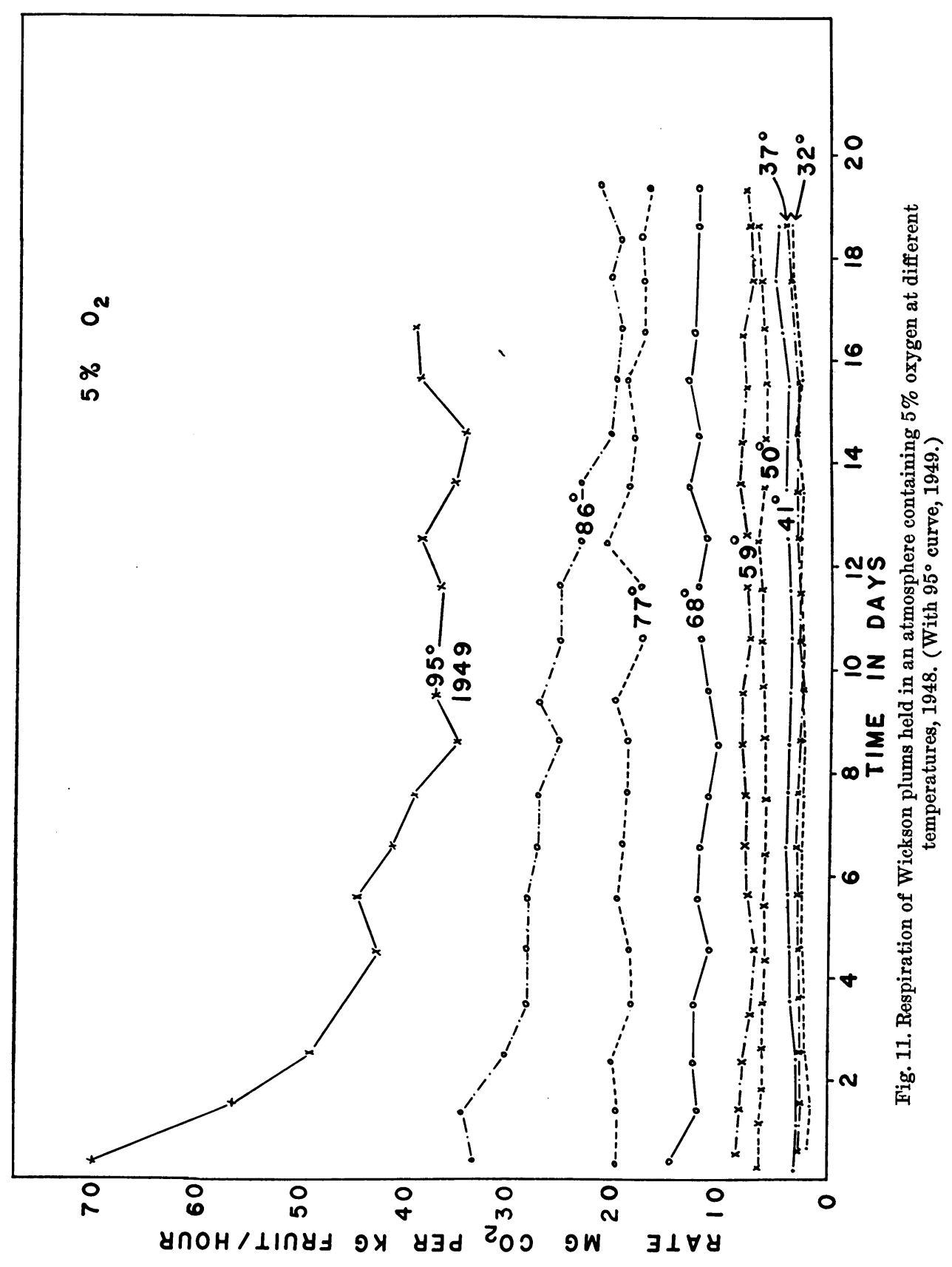


21 per cent Oxygen. When stored in air (figure 12) the respiration rates increased with temperature through $77^{\circ} \mathrm{F}$. However, a further increase to $86^{\circ} \mathrm{F}$ resulted in a higher early level which gradually diminished with time, so that it was exceeded by the $77^{\circ} \mathrm{F}$ lot after three days and by the $68^{\circ} \mathrm{F}$ lot after 15 days. The highest initial level was at $95^{\circ} \mathrm{F}$. This was followed by a rapid early reduction in rate, leveling off in about a week. It was surpassed

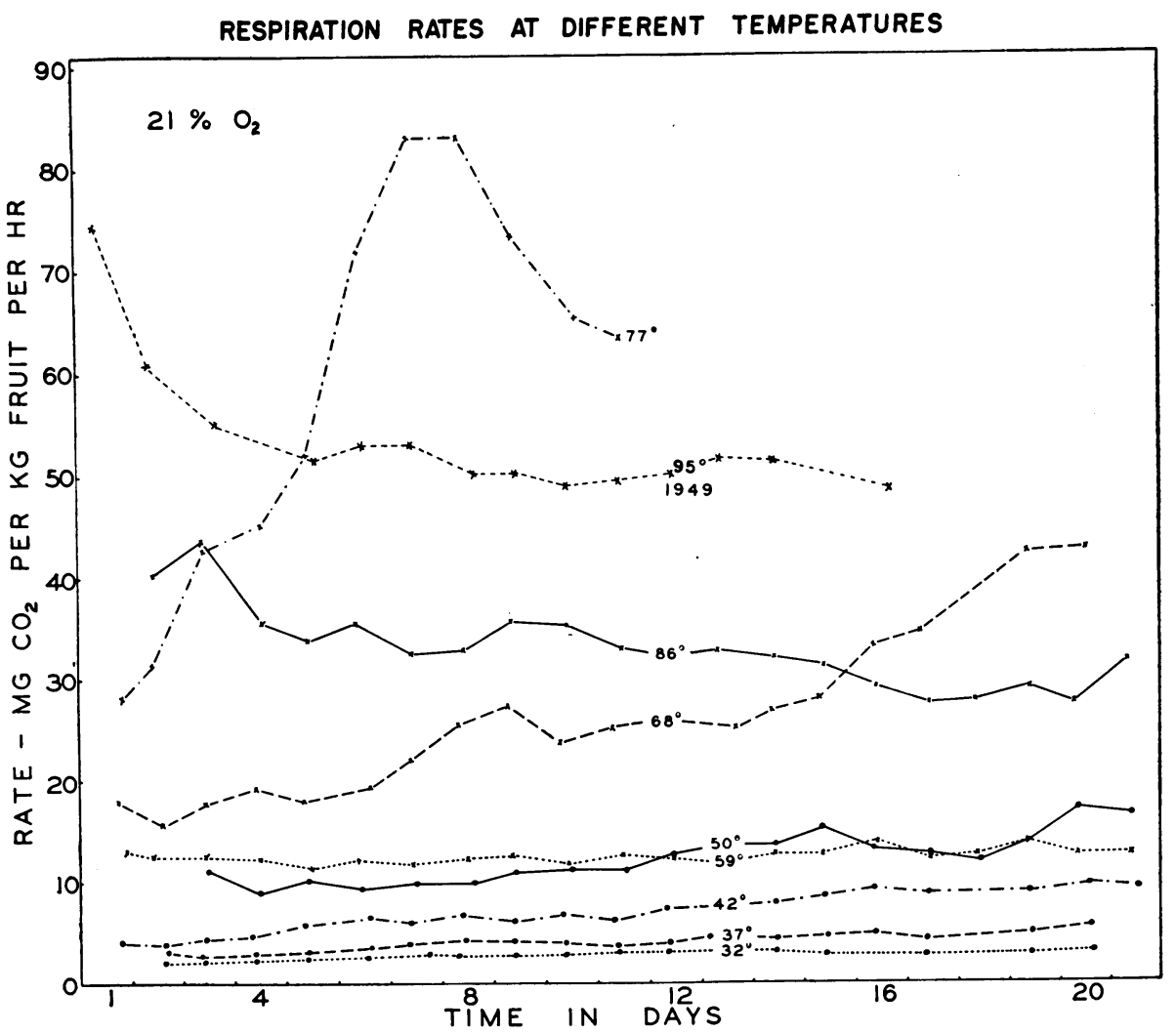

Fig. 12. Respiration of Wickson plums held in air at different temperatures, 1948. (With $95^{\circ}$ curve, 1949.)

by the $77^{\circ} \mathrm{F}$ lot after six days, but by no other during the experimental period. The $77^{\circ}$ and $68^{\circ} \mathrm{F}$ lots were the only two where marked increases in respiration rate occurred with time. Others remained nearly constant, increasing only slightly with time.

75 per cent Oxygen. In 75 per cent oxygen (figure 13) the respiration rates again increased with temperature through $77^{\circ} \mathrm{F}$. At $86^{\circ} \mathrm{F}$ the acceleration in respiration rate and the climacteric peak attained were less than at $77^{\circ} \mathrm{F}$, but somewhat greater than at $68^{\circ} \mathrm{F}$ and below. At $95^{\circ} \mathrm{F}$ the respiration rate was initially the highest of any but instead of increasing toward the climacteric peak as ripening progressed, it made a rapid early decline into the fifth 
day, followed by a relatively level period throughout the remainder of the treatment. At all temperatures except $95^{\circ} \mathrm{F}$ there was some acceleration in respiration rate with time, which became marked at $59^{\circ} \mathrm{F}$ and above.

\section{Fruit Ripening}

As previously stated, color readings were made on a numerical scale for all lots at intervals during the period of differential treatment. These readings were continued after the fruits had been removed to air at $68^{\circ} \mathrm{F}$ until they

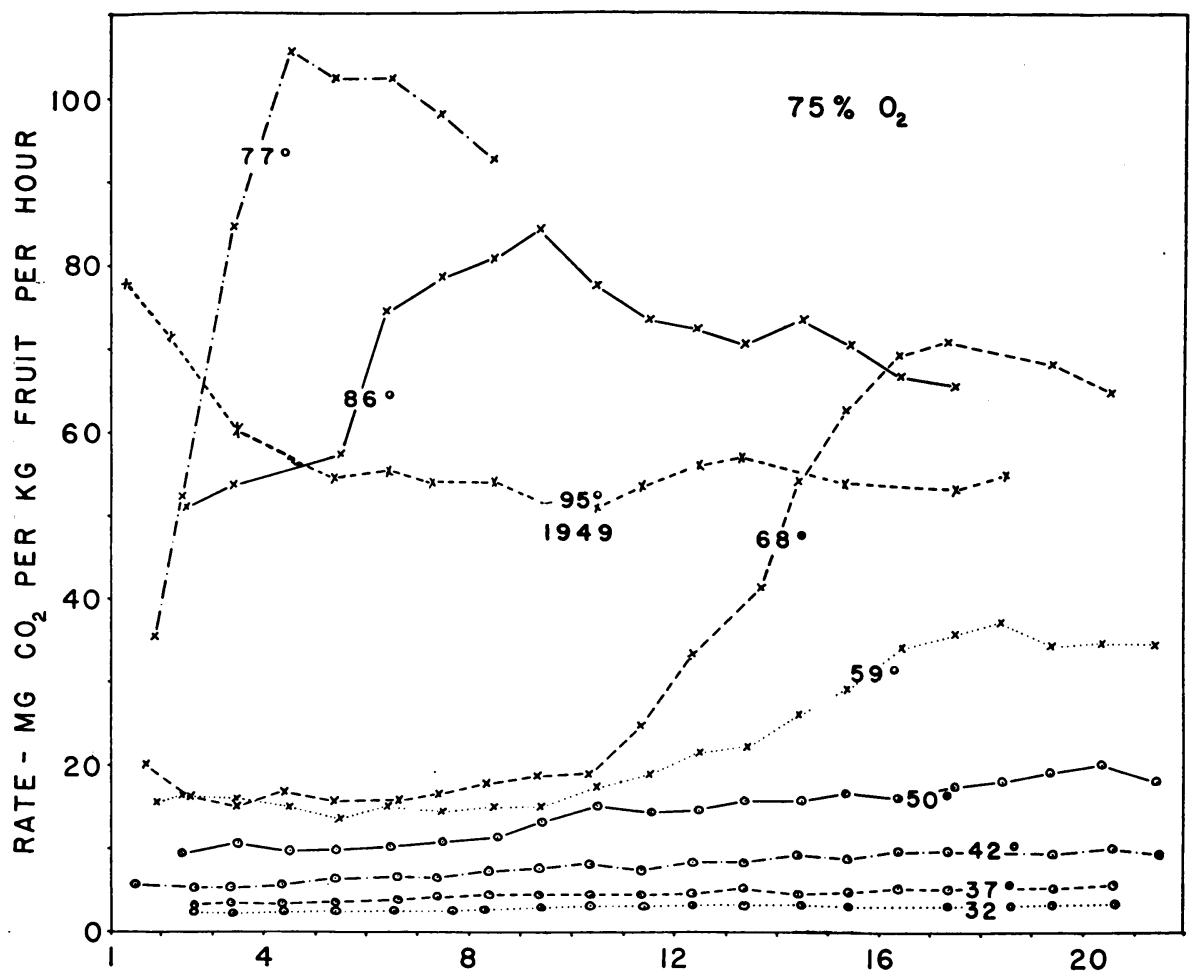

Fig. 13. Respiration of Wickson plums held in an atmosphere containing $75 \%$ oxygen at different temperatures, 1948 . (With $95^{\circ}$ curve, 1949.)

attained full color. Only the curves for the three temperatures, 68,77 , and $86^{\circ} \mathrm{F}$ (figures 14, 15 and 16 ) are presented, as these include nearly all of the lots which ripened during the period of differential treatments. Ripening of fruits held at $95^{\circ} \mathrm{F}$ in 1949 is discussed, but no curve is shown due to the abnormal behavior. The curves shown are also representative of those at lower temperatures in the correlation of respiration and ripening rates.

At $68^{\circ} \mathrm{F}$. Readings at $68^{\circ} \mathrm{F}$ (figure 14) show changes in fruit color to be closely associated with respiration rate. For the first seven days ripening progressed most rapidly in the 30 and 21 per cent oxygen lots, followed by the 50 and 75 per cent lots. After seven days, the 21 per cent lot began to lag and was passed in color development by both the 50 and 75 per cent lots. The 


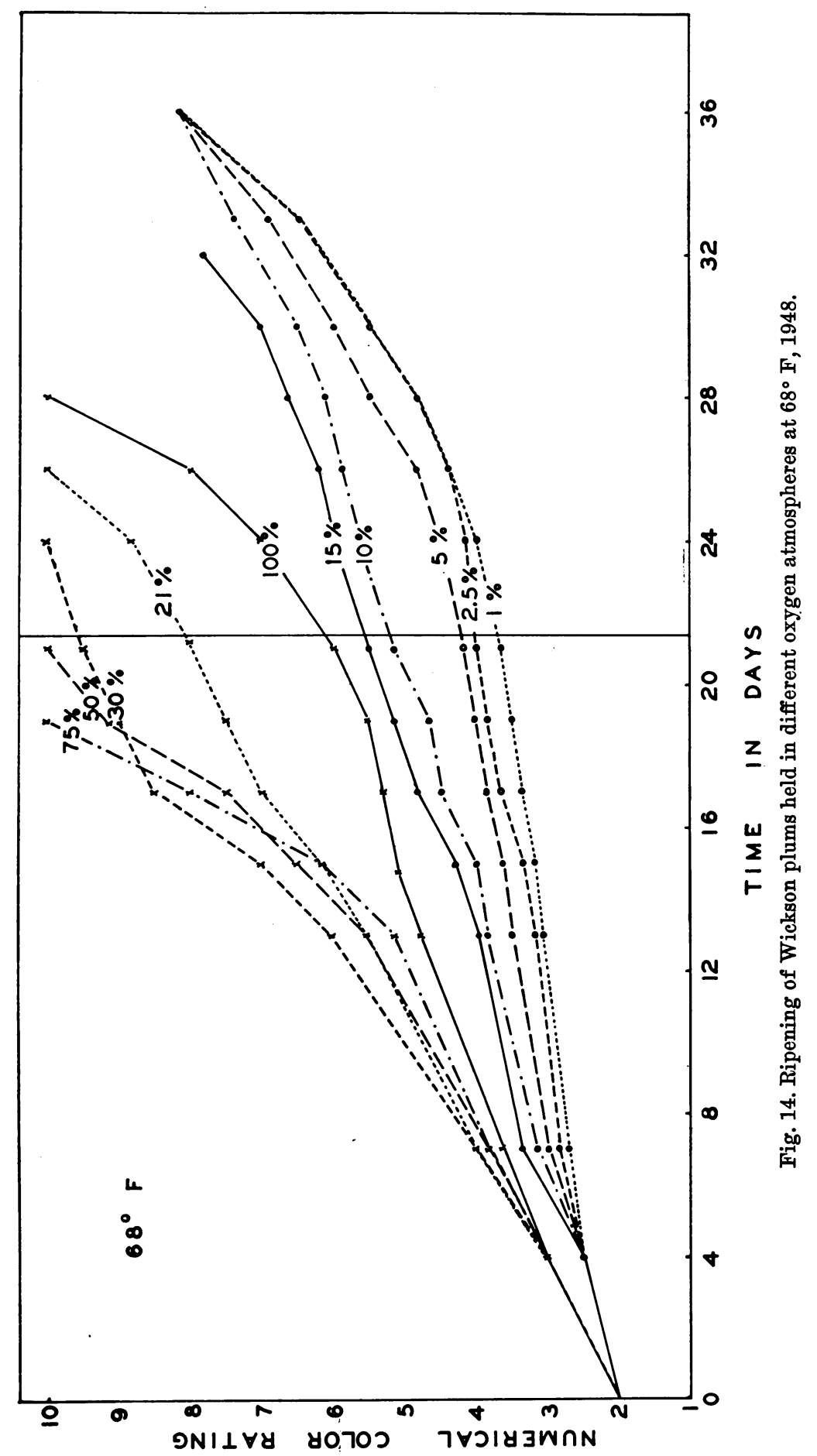


30 per cent lot maintained its riper position until near the end of the period of differential treatment, when it was passed by both the 75 and 50 per cent lots. These latter two attained full color first. Of interest in this connection is the 100 per cent oxygen lot, which maintained a ripening position intermediate between the 21 and 15 per cent lots, the same position it held in respiration. When duplicate lots in 100 per cent oxygen were repeated in 1949 , ripening was more rapid than at any other oxygen level including the same series of air and above, except for 75 per cent oxygen. This is evidence that the 1948 ripening curve in 100 per cent oxygen was abnormal and should be discounted the same as the respiration curve. The 1 and $21 / 2$ per cent oxygen lots had the least color change during the 21-day test period. This is in contrast to the positions they held in respiration which were above those of both the 5 and 10 per cent oxygen lots, and supports the earlier contention that the higher apparent respiration rates were due in reality to the anaerobic phases not being balanced by aerobic phases of respiration. The ripening curves indicate that less energy to support ripening changes was developed at the 1 and $21 / 2$ per cent oxygen levels than at higher oxygen levels.

Full color development did not occur until two and three days subsequent to the climacteric peak. At the climacteric peak of respiration, color development usually had attained a numerical rating of about 7 . This rating is listed as reddish yellow and approximates the best ripeness for fresh consumption of this variety. Differences in ripeness between the low oxygen lots at the end of the 21-day test period diminished gradually as the fruits ripened in air at $68^{\circ} \mathrm{F}$.

At $77^{\circ} \mathrm{F}$. Ripening at $77^{\circ} \mathrm{F}$ (figure 15) was more rapid than at any other temperature. ${ }^{5}$ The relative positions of the ripening curves as measured by color changes were almost identical to the positions of the respiration curves except for the 1 and $21 / 2$ per cent oxygen lots. As at $68^{\circ} \mathrm{F}$, these latter two had the least color changes, although their respiration rates exceeded those of the 5 and 10 per cent oxygen lots. The 1 and $2 \frac{1}{2}$ per cent oxygen lots failed to ripen normally, the 1 per cent lot remaining firm and tough whereas the $21 / 2$ per cent lot developed flesh-browning. Other lots ripened normally. Here also the climacteric peak of respiration occurred at about a color rating of 7 .

At $86^{\circ} \mathrm{F}$. Ripening at $86^{\circ} \mathrm{F}$ (figure 16) follows a similar pattern to that found at 68 and $77^{\circ} \mathrm{F}$, that is, the faster the respiration rate the more rapid the color change. The fruit in the $1,21 / 2$ and 5 per cent oxygen lots failed to ripen normally, developing considerable flesh-browning by the time a greenish yellow color had been attained on the surface.

At $95^{\circ} \mathrm{F}$. None of the fruit held at $95^{\circ} \mathrm{F}$ ripened normally, as based upon our usual considerations of color and softening changes. There was, however, great variability between lots. All those in 10 per cent oxygen or less developed internal browning and became soft and mealy without developing characteristic color changes. Those lots of fruit held in 15 per cent or more oxygen

${ }^{5}$ In earlier ripening tests by Pentzer and Allen (1944) Wickson and Kelsey plums held at temperatures of $32,45,50,55,65$, and $80^{\circ} \mathrm{F}$, ripened most rapidly at $55^{\circ}$. At $50^{\circ}$ and at $55^{\circ}$ it was necessary to use cabinets for storage chambers and although these were ventilated frequently it would appear, in the light of these present experiments, that ripening at these temperatures may have been accelerated by some accumulation of volatiles. 


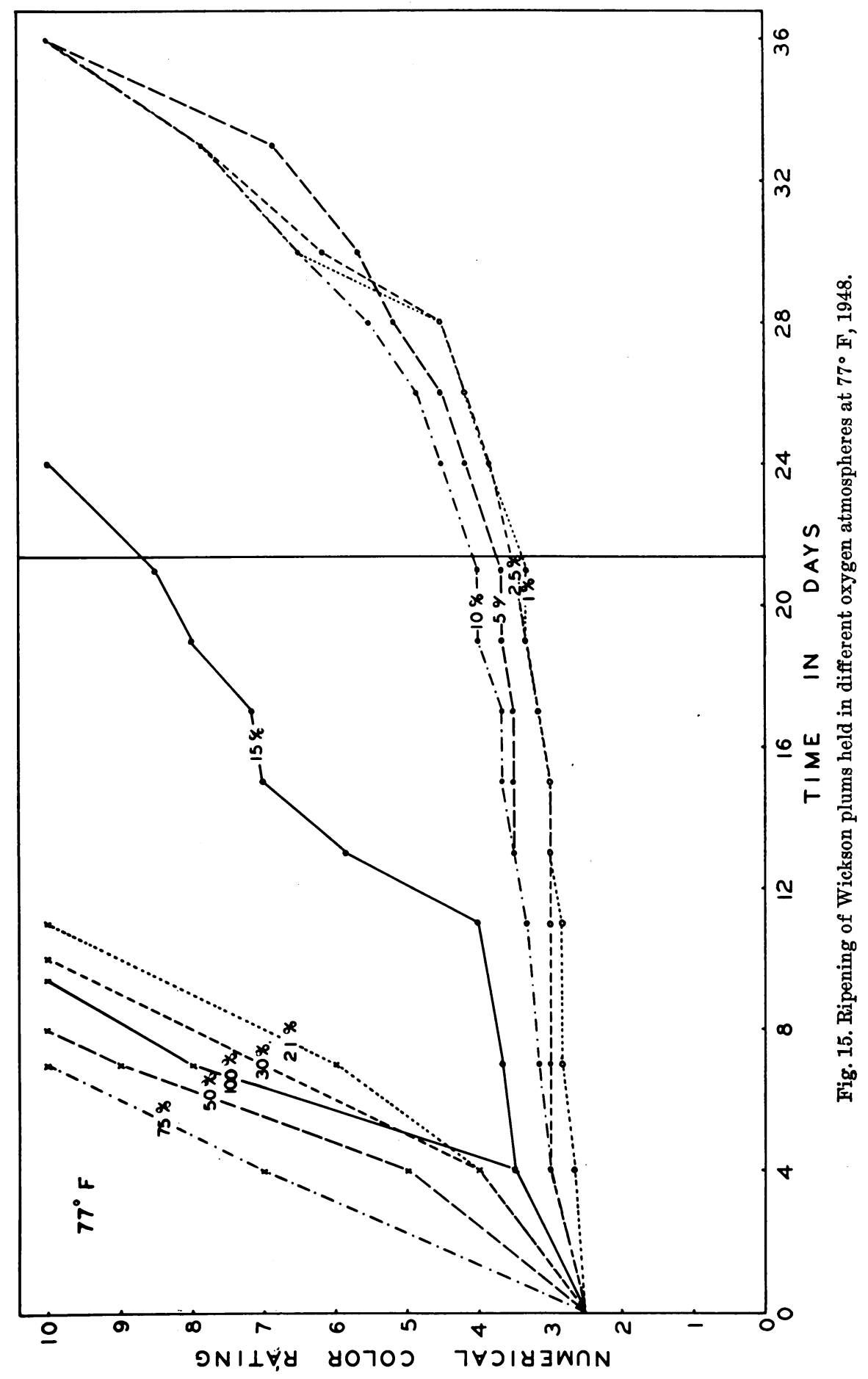




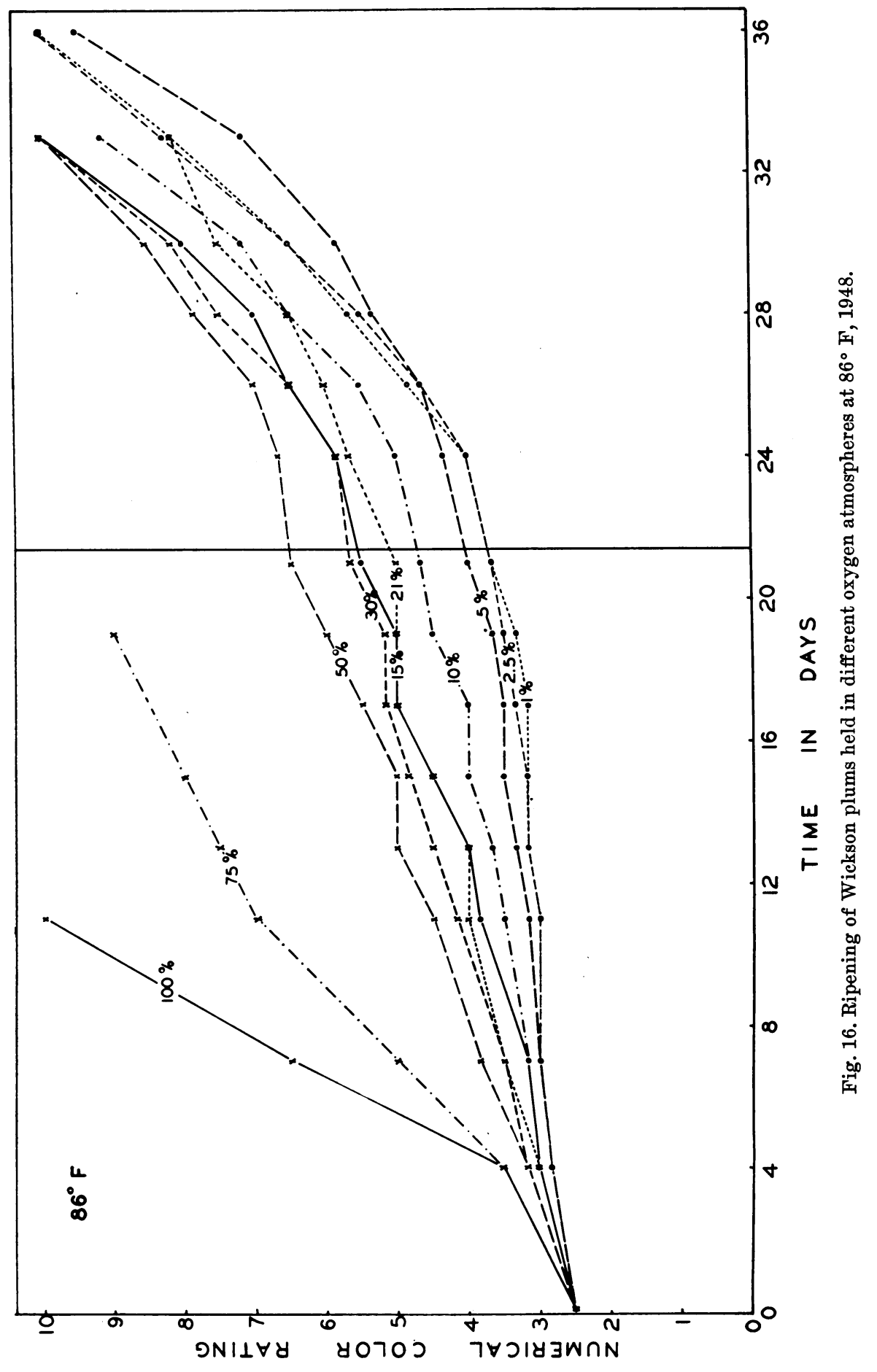


did finally attain full color, but not until several days after removal to air at $68^{\circ} \mathrm{F}$. The order of attainment of full color was directly related to the amount of oxygen in the atmosphere during the treatment period, the 100 per cent oxygen lot reaching full color first. Fruits of all lots appeared to have less vitality than at any other temperature as indicated by susceptibility to the attack of fungi, primarily Aspergillus sp., which are ordinarily saprophytic in nature. Whether the influences on ripening were due to an upset of enzymatic balances caused by high temperature, or oxygen relationships, is not known, but certainly the influence on vitality was great. The lots where the least decay developed were the 21 to 75 per cent series whereas those most affected were the 100 per cent and the low oxygen series. We can offer no explanation for the low vitality of the 100 per cent lot, as it was as near normal in color attainment and respiration as any. The low vitality of the low oxygen lots might, of course, be expected from the combined oxygen-temperature effects.

\section{Flavor Development}

As the fruit of each lot ripened it was tasted to determine the influence of the treatment on flavor. Fruits of lots that had flesh-browning near the pit, or that failed to soften properly after reaching full color, had an offensive odor and flavor. This was true of the 1 per cent oxygen lot at $59^{\circ} \mathrm{F}$, the 1 and $21 / 2$ per cent lots at all temperatures of $68^{\circ} \mathrm{F}$ and above, the 5 per cent lots at 86 and $95^{\circ} \mathrm{F}$, and the 10 per cent lot at $95^{\circ} \mathrm{F}$. All lots held in differential treatments at temperatures of $59^{\circ} \mathrm{F}$ and below ripened normally when moved to air at $68^{\circ} \mathrm{F}$, as indicated by proper softening and the development of normal flavors. At 86 and $95^{\circ} \mathrm{F}$ the lots of fruit that were considered normal because of no off-flavors were nevertheless poor in quality, lacking somewhat in sweetness and acidity but even more in characteristic aromatic flavor.

\section{Total Production of Carbon Dioxide}

If the total amounts of carbon dioxide produced by each lot of fruit during 20 of the 21 days in differential treatment are plotted with oxygen level against temperature, the curves secured are as shown in figure 17. The points representing the 21 to 100 per cent oxygen lots at $77^{\circ} \mathrm{F}$, the 100 per cent oxygen lot at $86^{\circ} \mathrm{F}$ and all lots at $95^{\circ} \mathrm{F}$ are from extrapolated figures based on the average carbon dioxide production of these lots during the shortened period they were under test. Because of extrapolation the points indicated may be either too high or too low, depending on what the respiration rates would have been had it been possible to continue them for the full period. If the period had been shortened to ten days, most of these same lots would be much higher proportionately than they are on figure 17.

The general trend is for the total $\mathrm{CO}_{2}$ respired to increase with temperature up to $77^{\circ} \mathrm{F}$. Above this temperature there is a falling off of $\mathrm{CO}_{2}$ production at oxygen levels of 15 to 75 per cent, a large increase at the 100 per cent oxygen level, and a small increase at 10 per cent oxygen and below. The behavior of the 1 and $21 / 2$ per cent oxygen curves shows that at 68 and $77^{\circ} \mathrm{F}$ the amount of $\mathrm{CO}_{2}$ produced was greater than that produced by either the 5 or 10 per cent oxygen lots. This is another indication that anaerobic respiration accounted for an important part of the $\mathrm{CO}_{2}$ measured for these lots. The points repre- 


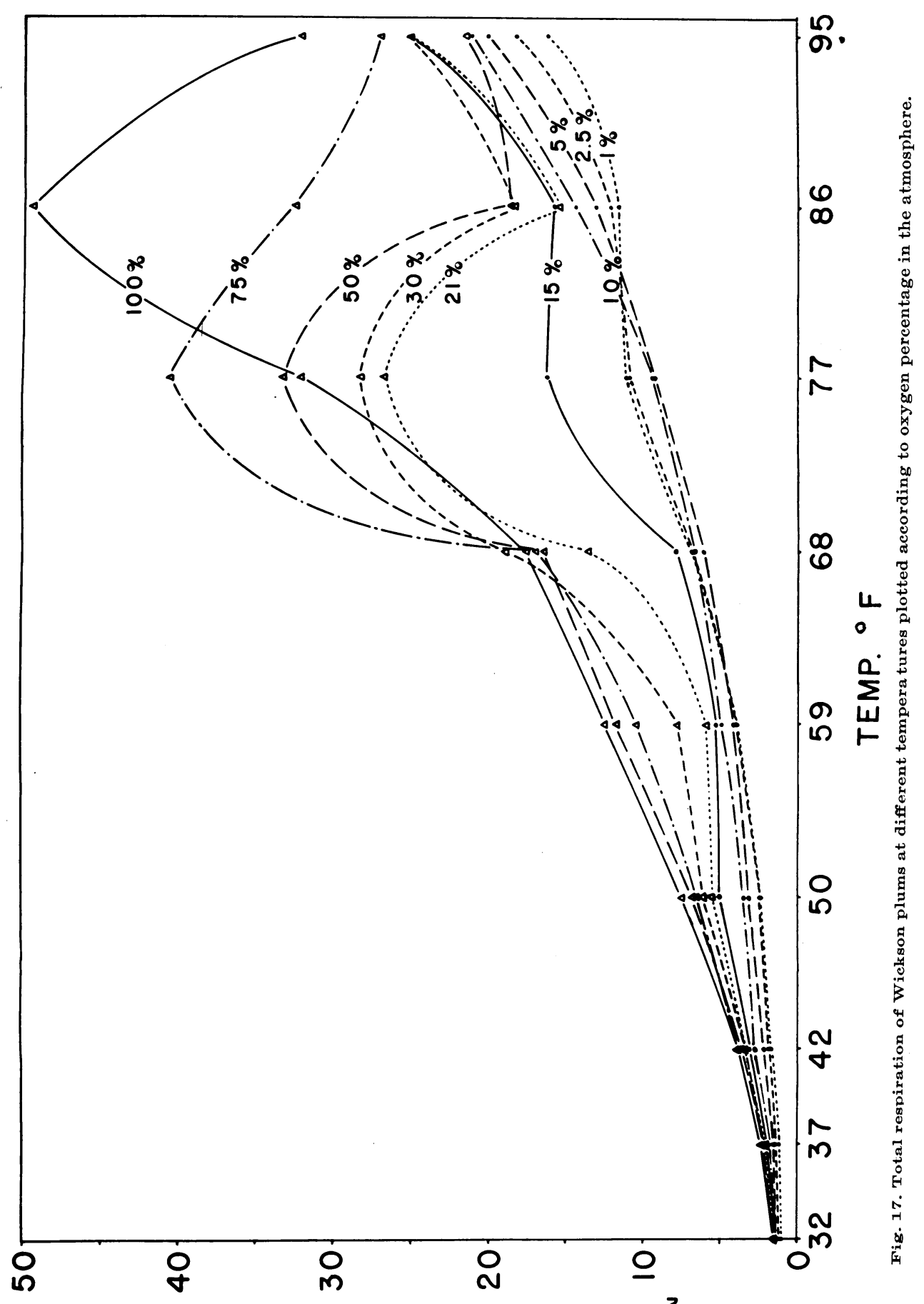

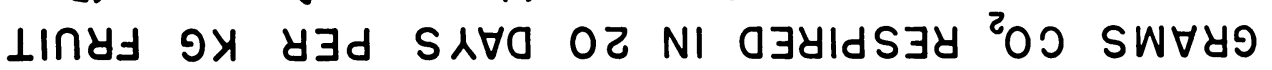


senting the 15 per cent oxygen lot at $50^{\circ} \mathrm{F}$, and the 100 per cent oxygen lot at $68^{\circ} \mathrm{F}$ are from 1949 duplicate lots, as the 1948 data appeared definitely out of position.

\section{Color Attainment as Related to Carbon Dioxide Production}

Several investigators (Kidd and West, 1930; Smock, 1942 ; Biale, 1946 ; and Allen and Claypool, 1948) have reported an apparent relationship between the storage life of a given fruit at cold storage temperatures and the amount of carbon dioxide respired during storage. Nearly equal cumulative amounts of $\mathrm{CO}_{2}$ were produced between harvest and the approximate end of the commercial storage life of apples, pears, or avocados when fruits were held under different temperatures or modified atmospheres. These results indicated the possibility of using the respiration rate to predict the relative storage lives of comparable lots of fruit held under different conditions. Data were secured with the Wickson plums in this test to determine if the same relationship existed. These data are presented in Table 1.

The cumulative weight of carbon dioxide produced was measured at the attainment of color 5 (yellow) and color 7 (reddish yellow). Since color 7 corresponds closely to the climacteric peak of respiration and also to the desirable ripeness for eating the fruit, it was selected as the best stage of ripeness to use. However, only a few lots reached this stage during the 21-day period of differential treatment so that accumulations of $\mathrm{CO}_{2}$ were also calculated at a yellow color. All of the cumulative figures are in slight error as there is no measure of the amount of $\mathrm{CO}_{2}$ produced during the first day. However, respiration rates for this short period are quite similar, at least at any given temperature, so it would appear that any error in this regard would have little influence on relative $\mathrm{CO}_{2}$ cumulations.

At color 5 there seems to be no relationship between ripening and carbon dioxide production of fruits held either in similar atmospheres at different temperatures or different atmospheres at the same temperature. This lack of correlation largely results from data at the two higher temperatures, 77 and $86^{\circ} \mathrm{F}$. The total variation is greatest at $86^{\circ} \mathrm{F}$, where the 30 per cent oxygen lot respired more than the 100 per cent lot by 7000 milligrams of $\mathrm{CO}_{2}$. The greatest percentage difference is at $77^{\circ} \mathrm{F}$, where the 15 per cent lot respired 430 per cent as much $\mathrm{CO}_{2}$ as the 75 per cent lot to attain color 5 . The greatest efficiency in energy release as measured by $\mathrm{CO}_{2}$ evolution to attain color 5 is found at $77^{\circ} \mathrm{F}$, especially in the 75 per cent oxygen lot and to a lesser degree in the 50 and 30 per cent lots. The poorest efficiency is found at $86^{\circ} \mathrm{F}$, where as much as three to five times the $\mathrm{CO}_{2}$ is evolved as at comparable oxygen levels at $77^{\circ} \mathrm{F}$. The high $\mathrm{CO}_{2}$ production at $86^{\circ} \mathrm{F}$ in relation to color change may be evidence of anaerobic respiration.

At color 7 the data show a lesser range in percentage differences, but total differences in $\mathrm{CO}_{2}$ production are in most cases at least as great as at color 5 . The greatest ripening changes per unit of $\mathrm{CO}_{2}$ evolved are still found with fruits in high oxygen levels at $77^{\circ} \mathrm{F}$, and the least ripening changes in those which attain color 7 during the experiment are again found at $86^{\circ} \mathrm{F}$.

The varied relationships between the amount of carbon dioxide evolved and the number of days required to attain a color of 5 or 7 are interesting. 


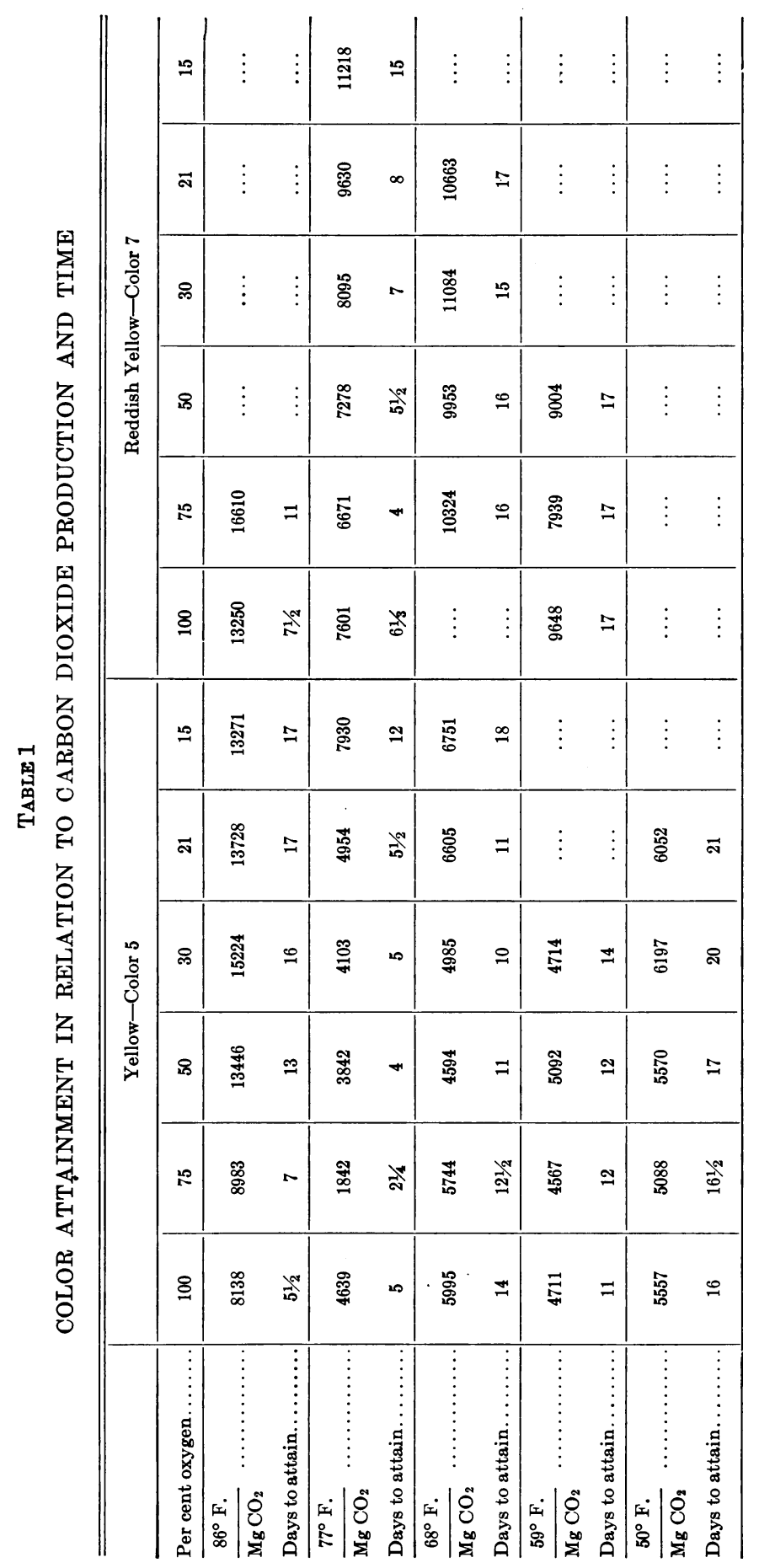


At any given temperature rapid ripening seems to be associated with relatively low total $\mathrm{CO}_{2}$ production for the ripening period. This might indicate a threshold level of respiration at which no ripening changes occurred. When comparisons are made of ripening at different temperatures, there appears to be little relationship between the time required for ripening and $\mathrm{CO}_{2}$ evolution during that period; e.g., the 100 per cent oxygen lots at $86^{\circ}$ and $77^{\circ} \mathrm{F}$ each required about the same time to attain a color of 5 , and yet 75 per cent more $\mathrm{CO}_{2}$ was evolved at $86^{\circ} \mathrm{F}$ than at $77^{\circ} \mathrm{F}$. Another comparison may be made between the 100 per cent lot at $77^{\circ}$ and the 50 per cent lot at $68^{\circ} \mathrm{F}$, each of which had evolved about the same amount of $\mathrm{CO}_{2}$ during ripening, while taking 5 and 11 days respectively to ripen.

From the data it appears that the amount of carbon dioxide evolved from Wickson plums under the conditions of the experiment is not a direct function of the ripening rate.

\section{DISCUSSION}

The experiments discussed in this report were designed to study the influence of temperature and oxygen level on the rate of respiration under conditions where the air flow was considered to be sufficiently rapid to eliminate the influences of product emanations from the fruit. This was accomplished reasonably well. However, the erratic behavior of one of the two 100 per cent oxygen lots at $68^{\circ} \mathrm{F}$ in 1949 raises the question as to just how rapid an atmospheric change is necessary to eliminate influences which emanations of one fruit in a lot may have on the others. The fact that the removal of one prematurely ripening plum, from a lot where new atmosphere was being delivered at the rate of $150 \mathrm{cc}$ per minute to give a calculated complete change every 15 minutes, resulted in a delay in ripening of remaining fruits, would seem to indicate that atmospheric exchange was not rapid enough in this instance.

The data show a general trend in the Wickson plum to increase respiration rate both with increasing temperature and increasing partial pressure of oxygen. Acceleration of respiration by raising the temperature has been well known for many years. This study serves not only to verify the results of such other studies, but also to point out that at any oxygen level a rise in temperature, up to a point, results in an increased respiration rate of the Wickson plum.

The influence of the oxygen tension on the respiration rate of fruits has been observed previously, but primarily at levels below that in air. The marked response of the Wickson plum to oxygen concentrations greater than that in air has not been reported for other fruits, although Biale and Young (1947) have shown a considerable response by lemons, and Biale (1946) some response by avocados. Our studies with other species of stone fruits have shown no response to oxygen concentrations greater than that in air, but the experiments have been limited in this regard. The fact that respiration as measured by $\mathrm{CO}_{2}$ production is accelerated even at cold storage temperatures as the partial pressure of oxygen is increased above that in air, would indicate that metabolic processes can be accelerated in the Wickson plum by oxygen levels greater than those required for normal metabolism. Whether this is 
due to an increased production of some active emanation such as ethylene is not known, but it seems doubtful that it is related to the balance between anaerobic and aerobic phases of the normal respiration process, especially at low and intermediate temperatures.

We believe the behavior of the low oxygen series in relation to temperature to be one of the most interesting findings of these experiments. At temperatures below $50^{\circ} \mathrm{F}$, respiration at oxygen tensions below that in air was pretty much proportional to the oxygen concentration. At $50^{\circ} \mathrm{F}$ there is a slight divergence from this behavior, as the 1 per cent lot respired as much $\mathrm{CO}_{2}$ as the $21 / 2$ per cent. This might be overlooked as an error in measurement were it not that at higher temperatures the divergence becomes increasingly greater and effects higher oxygen levels. At $59^{\circ} \mathrm{F}$, the 1 and $21 / 2$ per cent oxygen lots after a few days respire as much $\mathrm{CO}_{2}$ as the 5 per cent lot. At $68^{\circ} \mathrm{F}$ these same two lots progressively attain and surpass the 5, 10 and 15 per cent oxygen lots in $\mathrm{CO}_{2}$ production, and the 5 per cent lot approaches closely the $\mathrm{CO}_{2}$ production of the 10 per cent lot. At $77^{\circ} \mathrm{F}$, the $1,21 / 2,5$ and 10 per cent lots soon reverse completely their original positions so that the $\mathrm{CO}_{2}$ produced by the 1 per cent oxygen lot $>2 \frac{1}{2}$ per cent lot $>5$ per cent lot $>10$ per cent lot. At $86^{\circ} \mathrm{F}$, the relative positions of the various oxygen lots seem back to normal after the first few days, during which the 1 and $21 / 2$ per cent lots have produced relatively large amounts of $\mathrm{CO}_{2}$. At $95^{\circ} \mathrm{F}$, after very high initial rates of $\mathrm{CO}_{2}$ production, the $1,21 / 2$ and 5 per cent lots dropped to relatively low levels and to what might be considered their normal positions. Ripening curves and observations regarding condition and flavor of the fruits in various lots indicate rather conclusively, we believe, that anaerobic respiration only partially balanced by aerobic respiration occurred in all low oxygen lots where $\mathrm{CO}_{2}$ production was equivalent to or greater than that of the next higher oxygen lot. Unfortunately, it was impossible with an experiment of this magnitude to measure oxygen consumption simultaneously, which would have permitted calculating the respiration quotient. This would have been desirable at least for those lots where anaerobic respiration seemed to predominate. The ripening of fruits in low oxygen concentrations as measured by color changes and edibility was always closely related to the oxygen level. It seems likely, therefore, that greater $\mathrm{CO}_{2}$ production in some of these low oxygen lots was not the result of greater metabolic activity but rather of greater $\mathrm{CO}_{2}$ production through decarboxylation. Furthermore, the offensive aldehydic and alcoholic odors and flavors which developed in low oxygen lots, and the failure of those lots to ripen normally, is additional evidence of insufficient oxygen for normal respiration. At $86^{\circ}$ and $95^{\circ} \mathrm{F}$ the accumulation of toxic respiration intermediates was apparently so great that much protoplasm was killed, as indicated by browning of the tissues in the central and inner part of the flesh. No doubt this accounts for drops in $\mathrm{CO}_{2}$ production by these lots after high initial rates.

These results indicate that for the Wickson plums in this experiment the threshold level of respiration below which an apparent Pasteur effect becomes evident is variable with temperature. At $42^{\circ} \mathrm{F}$ and below it would seem that 1 per cent oxygen was at least as high as the threshold level, at $50^{\circ} \mathrm{F}$ the level was probably between 1 and $2 \frac{1}{2}$ per cent, at $59^{\circ} \mathrm{F}$ between $2 \frac{1}{2}$ and 5 
per cent, at $68^{\circ} \mathrm{F}$ a little above 5 per cent, and at $77^{\circ} \mathrm{F}$ near 10 per cent. At $86^{\circ} \mathrm{F}$ and $95^{\circ} \mathrm{F}$ the respiration curves do not lend themselves to further analysis in this respect, but fruit ripening and flavors indicate a further advance in the threshold level of oxygen. This behavior is as expected in accordance with the greater oxygen requirement for respiration and lower solubility of oxygen as temperature increases. Fürthermore, the Wickson plum is well protected by a thick cuticle which greatly restricts the exchange of gases in comparison with most stone fruits. All of these factors tend to reduce the accessibility of oxygen to tissues deep within the fruit and to develop anaerobic conditions first in that region.

At $86^{\circ}$ and $95^{\circ} \mathrm{F}$, the abnormal behavior of the respiration curves would indicate that some factor other than oxygen supply had assumed major importance. Fruits at these temperatures were susceptible to the attack of Aspergillus sp. fungi especially at $95^{\circ} \mathrm{F}$. Since this organism, whose optimum temperature range is near $70^{\circ} \mathrm{F}$, is normally saprophytic, the indications are that some change in the chemical nature of the fruit has occurred, resulting in greatly reduced ability of the fruit to resist the attack of organisms. Fruit held at these high temperatures is lacking both in sweetness and acid to the taste. It seems probable then that the activity of some of the enzymes involved in the overall respiration process is greatly reduced at temperatures of $86^{\circ}$ and $95^{\circ} \mathrm{F}$. Studies of the nature of these enzymatic and chemical changes would be worth while.

\section{SUMMARY}

This paper reports on the respiration and ripening of Wickson plums held in ten oxygen levels, ranging from about 1 to 100 per cent at each of nine temperatures, ranging from about $32^{\circ}$ to $95^{\circ} \mathrm{F}$. Most of the data were secured in 1948, following preliminary studies the preceding year, while some additional studies were made in 1949. Daily respiration determinations and other observations were made over a 21 -day treatment period. Respiration readings were limited to carbon dioxide production. A gas stream of desired composition was constantly passed over all lots of fruit to avoid the accumulation of volatiles.

Initial carbon dioxide production was greatly influenced by temperature, increasing progressively with higher temperature throughout the entire sequence. At $86^{\circ}$ and $95^{\circ} \mathrm{F}$ the initial high carbon dioxide production was not maintained, dropping off with time at most oxygen levels, and failing for the most part to develop climacteric peaks. Fruits held at $77^{\circ} \mathrm{F}$ attained earliest and highest respiration peaks and ripened at faster rates than fruits held at any other temperatures.

Fruits held in oxygen levels above that in air were accelerated both in ripening and respiration rates. The rate of acceleration was usually somewhat proportional to the oxygen tension. At oxygen levels below that in air fruit ripening was delayed, the greatest delay being at the 1 per cent oxygen level. Carbon dioxide production was similarly reduced at temperatures of $32^{\circ}, 37^{\circ}$ and $42^{\circ} \mathrm{F}$, but at higher temperatures the fruits in the lowest oxygen levels began to produce as much or more $\mathrm{CO}_{2}$ as fruits in oxygen levels next above them, until at $77^{\circ} \mathrm{F}$ the 10 per cent oxygen lot was surpassed in $\mathrm{CO}_{2}$ 
production by fruits in all three lower oxygen levels in reverse order to that normally found. This behavior is attributed to anaerobic respiration not balanced by the aerobic phases. This possibility is supported by failure of such lots of fruit to ripen normally, and the development of physiological breakdown and objectionable flavors in them.

Fruit held at $86^{\circ} \mathrm{F}$ ripened to very poor quality, being low in both sugar and acid. At $95^{\circ} \mathrm{F}$ normal ripening failed to occur at any oxygen level and the fruits lost their vitality as indicated by susceptibility to a normally saprophytic fungus, Aspergillus sp. It is thought that abnormal ripening and loss of vitality of fruits at $86^{\circ}$ and $95^{\circ} \mathrm{F}$ resulted from influences of high temperature upon the enzyme systems in addition to the oxygen effect.

\section{LITERATURE CITED}

Allen, F. W., and L. L. Clatypool.

1948. Modified Atmospheres in Relation to the Storage Life of Bartlett Pears. Amer. Soc. Hort. Sci. Proc. 52 : 192-204.

BIALE, J. B.

1946. Effect of Oxygen Concentration on Respiration of the Fuerte Avocado Fruit. Amer. Jour. Bot. 33 : 363-73.

1950. Postharvest Physiology and Biochemistry of Fruits. Plant Physiol. Ann. Rev. 1950 : 183-206.

BIALE, J. B., and R. E. Young.

1947. Critical Oxygen Concentrations for the Respiration of Lemons. Amer. Jour. Bot. 34: 301-09.

Claypool, L. L., and F. W. Allen.

1947. Modified Atmospheres in Relation to the Transportation of Deciduous Fruits. Amer. Soc. Hort. Sci. Proc. 49 : 92-98.

1948. Carbon Dioxide Production of Deciduous Fruits Held at Different Oxygen Levels during Transit Periods. Amer. Soc. Hort. Sci. Proc. 51: 103-13.

Claypool, L. L., and R. M. KeEFER.

1942. A Colorimetric Method for $\mathrm{CO}_{2}$ Determination in Respiration Studies. Amer. Soc. Hort. Sci. Proc. 40: 177-86.

GodDARD, D. R., and B. J. D. MEeuse.

1950. Respiration of Higher Plants. Plant Physiol. Ann. Rev. 1950 : 207-32.

KIDD, F., and C. WEST.

1930. Physiology of Fruit. 1. Changes in the Respiratory Activity of Apples during Senescence at Different Temperatures. Royal Soc. London Proc., Ser. B. 106: 93-109.

KIDD, F., C. West, and M. N. KIDD.

1927. Gas Storage of Fruit. (Spec. Rept.) Food Inv. Board. (London) 30 : 1-87.

Pentzer, W. T., and F. W. Allen.

1944. Ripening and Breakdown of Plums as Influenced by Storage Temperature. Amer. Soc. Hort. Sci. Proc. 44 : 148-56.

SMOCK, R. M.

1942. Influence of Controlled Atmosphere Storage on Respiration of McIntosh Apples. Bot. Gaz. 104 : 178-84. 
The journal Hilgardia is published at irregular intervals, in volumes of about 600 pages. The number of issues per volume varies.

Subscriptions are not sold. The periodical is sent as published only to libraries, or to institutions in foreign countries having publications to offer in exchange.

You may obtain a single copy of any issue free, as long as the supply lasts; please request by volume and issue number from:

\section{Publications Office \\ College of Agriculture \\ Berkeley 4, California}

The limit to nonresidents of California is 10 separate issues on a single order. A list of the issues still available will be sent on request. 